originalni

naučni

rad

dr Danica Prošić

Master World d.o.o., Beograd danicaprosic@eunet.rs

\title{
Rezime
}

Kamate kao finansijski institut već dugo predstavljaju bitan element $\mathrm{u}$ standardnom toku finansijskih transakcija. Ali, koliko god su zbog njihove uloge i važnosti normativno uređene i pod kontrolom odgovarajućih institucija, uvek izazivaju nova pitanja i dileme. Kamate, koje u osnovi predstavljaju novac plaćen ili zarađen radi upotrebe novca $\mathrm{u}$ određenom vremenskom periodu, po prirodi stvari, pretpostavljaju određena matematička pravila za njihov obračun. Pitanje pristupa obračunu po različitim metodima u startu menja obračunske odnose i bitno može povećati kamatnu obavezu. U praksi se neretko dešava da poslovni partneri odbijaju da priznaju naše kamate ili nam pod određenim izgovorom nastoje naplatiti više nego što se čini prikladnim. Ovaj rad doprinosi rasvetljavanju tih osetljivih pitanja koja se javljaju u vezi sa kamatama, ukazujući istovremeno i na skrivene zamke koje u sebi kriju određeni metodi obračuna kamata.

Ključne reči: diskontovana vrednost, inflacija, interna stopa prinosa, kamata, kamatni račun, kapitalizacija, vremenska vrednost novca

JEL: E43, G21 


\section{INTEREST AND HIDDEN TRAPS IN THE INTEREST RATE CALCULATION METHODS}

Danica Prošić, PhD

Master World d.o.o., Belgrade danicaprosic@eunet.rs

\section{Summary}

Interest rate as a financial institute has been for a very long time a significant element in the standard flow of financial transactions. Nevertheless, no matter how much they have been, in view of their role and importance, normatively regulated and kept under control of the competent institutions, they have always surfaced with new questions and dilemmas. Interests, which are basically representing the money paid or earned for a use of money over the given period of time, in their very nature designate certain mathematical rules for their calculation. The matter of approach to the calculation according to the different methods, from the very start changes calculation relationships and may significantly increase the interest payment liability. In practice, it often occurs that business partners are refusing to recognise our interest rates or under certain pretences are striving to collect more than is seemed appropriate. This paper tends to contribute towards clarification of these sensitive issues that appear in connection with the interest rates, while pointing out at the same time at some of the hidden traps concealed in certain methods of interest rate calculations.

Key words: discounted value, inflation, internal rate of return, interest rate, interest account, capitalisation, the time value of money

JEL: E43, G21

Paper received: 01.11.2013

Approved for publishing: 09.04.2014 


\section{Uvod}

Prema opštem teorijskom konceptu kamata je trošak pozajmljivanja novca. U makro razmerama kamata je finansijski instrument za razmenu tekućih finansijskih resursa za buduće finansijske resurse. Poznata je od najstarijih civilizacija i bila je zabranjena propisima mnogih religija. Judizam i Hrišćanstvo uzimanje kamate delimično ograničavaju. Islamsko bankarstvo koje se često smatra fenomenom modernog doba posluje po ekonomskim principima ali uz odsusutvo kamate. To ne znači da finansijer nema pravo na prinos od uloženih sredstava, već da se visina prinosa mora dovesti u vezu sa ekonomskim rezultatom finansijskog projekta (Marinković, 2013. p. 108). Kroz svoj rad The Theory of Interest, 1930. godine, Irving Fisher je delom doprineo razvoju modernog koncepta kamate. Vremenska vrednost novca, alternativne investicije, inflatorna očekivanja, rizik investicije i likvidnost su samo neki od razloga zašto se zahteva nadoknada u obliku kamate za posuđeni novac. Navedeni razlozi istovremeno predstavljaju ključne determinante visine kamatne stope. Novčana sredstva koja poseduje, preduzeće može da uloži u različite projekte na način da donosi neki profit. U slučaju pozajmljivanja novca taj profit se ne ostvaruje i on predstavlja "oportunitetni trošak", odnosno, propuštenu priliku za zaradom. Stoga se ta zarada iskazuje kao kamata. Dužnik koji kasni sa ispunjenjem novčane obaveze duguje, pored glavnice, i zatezne kamate koje su uvedene u cilju podsticanja blagovremenog i potpunog ispunjenja obaveza, ne samo $\mathrm{u}$ interesu poverioca, već i zbog stvaranja finansijske discipline, građanskog i poslovnog morala, što na kraju utiče na stanje u privredi. Kamata se izražava kroz kamatnu stopu koja u osnovi izjednačava buduće vrednosti novca sa sadašnjom vrednošću. Postoje razne kamatne stope: na hipotekarne kredite, na keš kredite, za automobile, za različite vrste obveznica. Razlikuju se dugoročne i kratkoročne kamatne stope, kao i kamatne stope na kredite koji se odobravaju poveriocima sa različitim kreditnim bonitetom, ali cilj ovog kratkog teksta nije da ulazi u detaljne podele i grupisanja kamatnih stopa. Predmet ovog rada je usmeren na razmatranje pojma kamate kao ekonomske i računovodstvene kategorije i različite načine njenog obračuna koji imaju svoje korene $u$ učenju o vremenskoj preferenciji novca u cilju davanja objašnjenja zbog čega je jedan način obračuna povoljniji od drugog.

\section{Različiti pogledi na kamate}

Pre razgraničenja različitih pogleda na kamate prisetimo se dobro poznate činjenice da kamate onima koji ih plaćaju uvek izgledaju previsoke, a onima koji ih naplaćuju niske. Međutim, na opštem ljudskom nivou to je verovatno jedina činjenica oko koje se ljudi dogovoraju, bez obzira na profesiju kojoj pripadaju. U svojoj osnovi kamata je naknada koja se plaća za upotrebu tuđeg novca i kao takva ima svoj ekonomski i pravni aspekt. Sa ekonomskog aspekta, kamata znači naknadu za korišćenje određenog iznosa novca dobijenog od strane poverioca na određeno vreme. Iznos kamate je u suštini funkcija tri varijable: pozajmljenog iznosa (kapitala), kamatne stope i vremenskog perioda na koji je kapital pozajmljen. Za davaoca kredita kamata je prinos na datu glavnicu, a za dužnika trošak. Kamate se uvek obračunavaju za neki osnovni vremenski period koji nazivamo, period kapitalizacije, što se propisuje zakonom ili definiše ugovorom. Ono što često zaboravljamo pri tumačenju perioda kapitalizacije, je to da nakon isteka jednog perioda kapitalizacije kamata počinje da egzistira kao samostalni kapital koji pod normalnim okolnostima može da počne da se reprodukuje i generiše nove kamate. Računovođe su često zatečeni između ekonomske logike i zakonskih okvira, stoga je njihov pristup ovoj problematici mnogo ozbiljniji nego što je to slučaj u drugim oblastima ekonomske profesije. Osnovna polazna tačka u ovoj oblasti su nesumnjivo računovodstveni standardi. MRS koji se posredno ili neposredno bave kamatama i kategorijama koje su s njima manje ili više neposredno povezane su:

- MRS 18 - Prihodi. Ovaj standard se primenjuje u računovodstvenom obuhvatu prihoda koji nastaju korišćenjem sredstava entiteta od strane drugih čime se ostvaruju kamate.

- MRS 23 - Troškovi pozajmljivanja. Troškovi pozajmljivanja su kamata i drugi troškovi koje entitet ima u vezi sa pozajmljivanjem. 


\section{Introduction}

According to the general theoretical concept, interest is the money borrowing cost. On the macro scale, interest is regarded as a financial instrument for exchange of current financial resources for the future financial resources. It has been known since times immemorial and the oldest civilisations and was prohibited under creeds of many religious beliefs. Judaism and Christianity alike have limited to an extent charges on interest imposed. Islamic banking that is often deemed to be a phenomenon of the modern times is operating along economic principles but with the exception of the interest charged. This does not imply that the financier has no right to receive return on his invested funds, but that the amount of the yield must be appropriate to the economic result of the financial project achieved (Marinkovic, 2013, p. 108). In his work entitled "The Theory of Interest", of the year 1930, Irwin Fisher contributed in part to the development of the modern interest concept. The time value of money, alternative investments, inflationary expectations, investment and liquidity risks were only some of the reasons why compensation is required in the form of the interest for the money borrowed. The above reasons also present key determinants in view of the interest rate amount. Money resources owned by a company may be invested in different projects in a profit-making manner. In case of money lending such profit is not achieved and it represents "opportunity cost", i.e. a lost opportunity to make gains. Hence such gains are presented as interest. The debtor defaulting on his servicing of debt liabilities, in addition to the principal amount and the penalty interests that are introduced for purpose of instigating timely and prompt servicing of liabilities, is not only held liable for the best interest of the creditor but also for creating financial discipline, civic and business ethics, which ultimately impacts the state of affairs of the economy in general. Interest is expressed through the interest rate which is basically equalising the future with the present value of money. There are different interest rates: on mortgage loans, on cash credits, on car purchasing loans, on different kinds of bonds. There is a difference between longterm and short-term interest rates, but also on credits granted to the creditors with different credit rating, but the purpose of this short text is not to venture into details of classification and groupings of the interest rates. The main purpose of this paper is focused on the examination of the notion of interest, both as an economic and an accounting category, and different ways of its calculation that have their roots in the teachings of the time preference of money, for purpose of offering explanations why one way of calculation is better than some other one.

\section{Different view on the interest rates}

Before we venture into differentiation of the different view on the interest, let us recall the well known fact that the interest always seems far too high to those who are paying it, and far too low to the ones collecting it. However, at a global human level, this may be the only fact that people are ready to talk about and agree upon, regardless of the profession that they enjoy. In its very nature, interest is a compensation which is to be paid for the use of some other person's money and as such has both its economic and legal aspects. From the economic point of view, interest means compensation for the use of a certain amount of money received from the creditor for a certain period of time. The amount of interest is essentially a function of the three variables: money borrowed (capital), interest rate, and the time period on which capital was borrowed. For the creditor, interest is the yield on loaned principal, and for the debtor it is the cost of borrowing. Interests are always calculated for a certain basic period of time which we call period of capitalisation, and is prescribed either by law or defined in the contract. What we often tend to forget when interpreting the period of capitalisation is that, after the elapse of one capitalisation period, interest starts to exist as an independent capital which under normal circumstances may start to reproduce and generate new interest. Accountants are often found stranded between economic logic and the legal framework, hence their approach to this problem is much more serious than is the case in other fields of economic profession. The basic point of departure in this field is undoubtedly the accounting standards. IAS 
- MRS32-Finansijskiinstrumentiobelodanjivanje $i$ prikazivanje. Standard se bavi izneđu ostalog i klasifikovanjem pripadajućih kamata, dobitka i gubitka.

- MRS39-Finansijski instrumenti: priznavanje i odmeravanje. Ovaj standard se bavi kamatnim stopama koje su predmet hedžinga.

Izvori prava predstavljaju sredstvo kojim se obezbeđuje primena načela pravne sigurnosti i jednakosti. Sveopštost našeg privrednog ambijenta pokriva Zakon o obligacionim odnosima (ZOO) - Ustavna povelja. O kamatama i njima srodnim kategorijama može se naći u poglavljima o različitim vrstama obaveza. Međutim, ono što je uočljivo već na prvi pogled je to da $\mathrm{u}$ ovom Zakonu ne postoji definicija kamate, što verovatno znači da se sa jedne strane smatra da je ova kategorija svakom građaninu u najmanju ruku sama po sebi razumljiva. Sa druge strane postoji donekle razumljiva "perverzija" jer se u delu koji se odnosi na plaćanje, kamata pominje mnogo puta. Osim ZOO kamate su u našoj zemlji regulisane i Zakonom o zaštiti korisnika finansijskih usluga, Zakonom o zateznoj kamati i Zakonom o bankama.

Primeri iz prakse pokazuju da su osnovne pretpostavke, tradicionalno sažete u pravnim sistemima neinflacijskih država izazivale dosta problema $\mathrm{u}$ vreme izuzetno visoke inflacije merene rastom cena na malo kada je dolazilo do depresijacija pojedinih valuta, a time i do realnog znatnog smanjenja obima novčanih obaveza. Disproporcija između eksterne moći valuta, kurseva propisanih od strane država i njihove kupovne moći je takva da je protokom vremena od nastanka novčane obaveze do dana plaćanja gotovo nemoguće održati ravnotežu između prava i obaveza iz ugovora. U tom smislu svakako su najvažnija sledeća polazišta za procenu novčanih obaveza:

1. Načelo monetarnog nominalizma (član 394. ZOO) ima za cilj pravnu sigurnost, što znači da dužnik u svakom trenutku zna koliko duguje, a poverilac koliko potražuje, međutim, ovo načelo može u uslovima nekontrolisane i galopirajuće inflacije postati pogubno za poverioce.

2. Zabrana kamate na kamatu (član 400. ZOO).

3. Kamata (član 558. ZOO) - u ugovorima u privredi zajmoprimac duguje kamatu i ako ona nije ugovorena.
4. Plaćanje pre roka (član 398. ZOO) - dužnik novčane obaveze može je ispuniti pre roka i ništava je odredba ugovora kojom se dužnik odriče ovog prava. U slučaju ispunjenja novčane obaveze pre roka, dužnik ima pravo da od iznosa duga odbije iznos kamate za vreme od dana isplate do dospelosti obaveze, samo ako je na to ovlašćen ugovorom ili to proizlazi iz običaja.

U nastavku ćemo uvažavajući navedene okvire fokusirati se na računska i šira metodološka pitanja povezana sa finansijskom matematikom i ekonomskom pozadinom koji određuju filozofiju pojedinog načina obračuna kamate.

\section{Vremenska vrednost novca}

Bez razumevanja vremenske vrednosti novca i kategorija koje su s njom povezane nije moguće donositi ispravne finansijske odluke, odnosno, efikasno upravljati finansijama. Vremenska vrednost novca proizlazi iz vremenske povlašćenosti koju novac ima. Povlašćenost se iskazuje u saznanju da novac više vredi danas od istog iznosa novca kasnije. Tako kredit mora doneti kamatu poveriocu, a investicija dobit investitoru. Preduzeća ulažu u materijalnu imovinu (imovina koju možete opipati, kao što su fabrike, mašine, kancelarije) i u nematerijalnu imovinu (patenti, robne marke, licence). U oba slučaja se određeni novac ulaže danas očekujući da će se zaraditi još više novca kasnije. Kada zajmodavac alocira zajmoprimcu novac, cena tog novca je kamatna stopa koja se zaračunava na posuđena sredstva. Najjednostavnije rečeno, kamatna stopa je koeficijent provizije koju moramo da platimo da bismo mogli da koristimo kredit, podeljen sa iznosom odobrenog kredita (Rosse, 2005. p. 199). Tako je iznos kamate u suštini funkcija tri promenljive varijable: pozajmljenog iznosa C (kapitala), perioda kapitalizacije izraženog u danima, mesecima ili godinama i kamatne stope $p$. Kada je u pitanju zavisnost između ovih varijabli neosporno je sledeće: a) veći iznos glavnice mora pri nepromenjenim drugim okolnostima poveriocu doneti veća primanja (kamate), preciznije, kamata je direktno proporcionalna glavnici i b) dugoročno korišćenje novca dužnika opterećuje visokim kamatama. 
which are directly or indirectly dealing with the interests and categories more or less thereby related, are the following:

- IAS 18 - Earnings. This standard is applied in the accounting treatment of earnings which derive from the use of the entity's funds by others, thus creating interest income.

- IAS23-Costs ofborrowing. Costs of borrowing designate interest and other costs incurred by an entity when borrowing money.

- IAS 32 - Financial instruments of disclosure and presentation. This standard treats, among other, classification of the appurtenant interest, profit and loss.

- IAS 39 - Financial instruments: recognition and measurement. This standard deals with the interest rates which are subject to hedging.

Sources of law are the means to provide for the application of the principle of legal security and equality. The global scope of our economic environment is covered by the Law on Obligations (Contract Law) - Constitutional Charter. Interest rates and related categories can be found in the chapters dealing with different types of obligations. However, what is obvious at a first glance is that in this Law there is no definition of the interest rate, which probably means that it is believed, on the one hand, that this category is well known and at least in itself familiar to every citizen, while on the other hand there is a rather understandable 'perversion' as in the part dealing with payments, interest is being mentioned many times. In addition to the Contract Law, interest rates in our country are also regulated under the Law on Protection of Users of Financial Services, and also in the Penalty interest law and the Banking Law.

Cases encountered in practice show that the main assumptions, traditionally summarized in the legal systems of non-inflationary states, have caused a lot of problems at the time of extremely high inflation measured by the growth of retail prices when depreciation of certain currencies occurs, and thus to a real significant fall in the volume of monetary obligations. Disproportion between extreme currency power, exchange rates prescribed by the states and their purchasing power is such that over a certain period of time, from the date of monetary obligation and up to the date of due payment it is almost impossible to maintain balance between the contractual rights and obligations.

In this sense certainly the most important are the following starting points for assessment of monetary obligations:

1. Principle of monetary nominalism (Article 394 of the Contract Law) is aimed at providing for legal surety, which means that the obligor shall know at all times how much he is indebted, while the creditor shall know how much he is claiming. This rule, however, in the situation of uncontrolled and galloping inflation can become disastrous for the creditors.

2. Ban on interest on interest (compound interest) (Article 400 of the Contract Law)

3. Interest rate (Article 558 of the Contract Law) - in the corporate contracting the borrower is held liable to repay interest although it is not contracted.

4. Prepayment (Article 398 of the Contract Law) - the debtor liable to service monetary obligation may repay it before the maturity date and the contractual provisions stipulating that the obligor has resign this right is deemed nil and void. In case of repayment effected before the maturity term, obligor shall have the right to deduct from the amount of debt outstanding the amount of interest for the period from the date of prepayment to the date of maturity, but only if he is so authorised under the contract, or so empowered under customary law.

Further in this paper we shall focus, while respecting the above mentioned scope, on the calculation and broader methodological matters related to the financial mathematics and economic background that define the philosophy of the particular manner in which the interest rate is calculated.

\section{The Time Value of Money (TVM)}

Without the assessment of the time value of money and the categories thereto related it is not possible to make correct financial decisions, i.e. to effectively manage finances. The time value of money derives from the time privilege or preference that the money has. Preference is expressed in the knowledge that the money is worth more today than the same amount will 


\section{Karakteristike različitih načina obračuna kamata}

Sa aspekta trenutka u kojem se vrši obračun kamate i sa aspekta osnovice za obračun kamate, postoje dva, u osnovi veoma različita načina - dekurzioni i anticipationi. U prvom slučaju obračun kamate i njeno dodeljivanje kapitalu vrši se na kraju svakog obračunskog perioda, dakle, unazad, a u drugom kamate se obračunavaju na početku perioda od glavnice $\mathrm{s}$ kraja perioda, dakle unapred.

\section{Slika 1. Dekurzivni i anticipativni obračun}

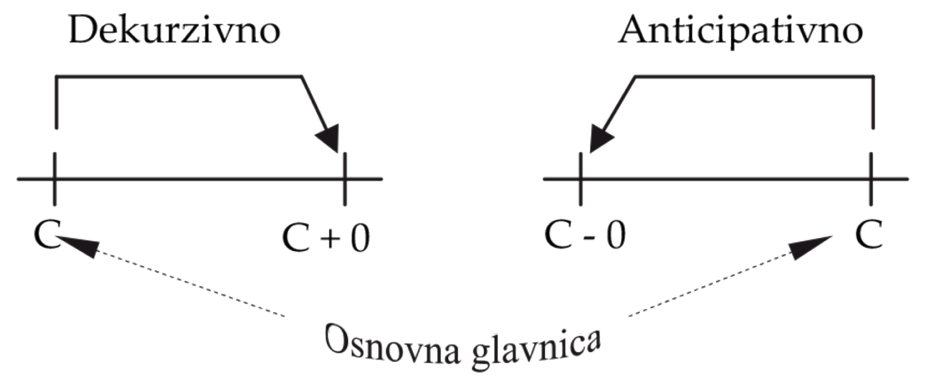

Izvor: Autorski prikaz

po anticipativnom metodu. U tom kontekstu se postavlja pitanje da li je $p$ dekurzivna kamatna stopa ekvivalentna anticipativnoj kamatnoj stopi $\pi$ na godišnjem nivou? Dve kamatne stope svaka sa svojim periodom kapitalizacije su ekvivalentne ako na istu glavnicu u istom periodu daju istu ukamaćenu vrednost. Pođimo od razumevanja sledeće jednakosti: dve su cene ekvivalentne ako imaju isto značenje i teret za dužnika, odnosno, ako imaju isti odnos kamate i kapitala koji mu je na raspolaganju:

1. dekurziono: na početku godine smo imali $\mathrm{C}$ novčanih jedinica i za njihovo korišćenje, na kraju godine smo platili $\mathrm{Cp} / 100$ novčanih jedinica kamate;

2. anticipativno: na početku godine smo imali $C$ novčanih jedinica i za njihovo korišćenje smo unapred platili: $\mathrm{C} \pi / 100$ novčanih jedinica kamate. Tako imamo:

$$
\frac{\mathrm{pC}}{100}: \mathrm{C}=\frac{\pi \mathrm{C}}{100}: \frac{(100-\pi) \mathrm{C}}{100} \Rightarrow \mathrm{p}=\frac{100 \pi}{100-\pi}
$$

Ispravnost obrasca možemo

Prvi način, koji smo više navikli da koristimo u svakodnevnoj praksi, čine kamate nakon isteka relevantnog perioda. Takva kamata se naziva dekurzivna a obračun dekurzivni. Drugi način je anticipativni koji predviđa da se kamata obračunava od glavnice na početku kamatnog perioda. Ovakav obračun je najčešće zastupljen kod kratkoročnih kreditnih i meničnih poslova. Dekurzivna kamatna stopa najčešće se označava slovom $p$, a anticipativna slovom $\pi$. Kod kamatnog računa primenjuju se i sledeće oznake (simboli): $\mathrm{C}_{0}=$ početna vrednost; $\mathrm{C}_{n}=$ konačna vrednost; $n=$ broj perioda; $\mathrm{k}=$ kamata. Radi lakšeg razumevanja problema analizirajmo sledeći hipotetički primer.

Preduzeću je odobren kredit od 1.000 dinara po kamatnoj stopi od $11 \%$ na godinu dana. Po dekurzivnom obračunu na kraju godine platiće 110 dinara kamate. Primenom anticipativnog obračuna se dobije isti iznos od 110 dinara koji će biti oduzet od glavnice u momentu uzimanja kredita, zapravo koristiće samo 890 jedinica kapitala. Drugim rečima: za potpuno istu uslugu (kredit) banci će platiti istu naknadu ali čak godinu dana ranije ako se obračun kamata vrši da proverimo pomoću podataka iz prethodnog primera, ili još bolje, ako aktivno rešimo zadatak uz veće kamatne stope, na primer, $31 \%$ godišnje.

$$
\mathrm{P}=\frac{100 \pi}{100-\pi}=\frac{100 \times 31}{100-31}=44,927536 \ldots \%
$$

Na osnovu dobijenog rezultata možemo da zaključimo: unapred plaćenih 31 posto anticipativnih kamata na godišnjem nivou je ekvivalent plaćanja gotovo 45 posto dekurzivnih kamata. Stoga je anticipativni obračun kamate uz istu kamatnu stopu za korisnika kredita skuplji nego dekurzivni. S obzirom da je anticipativni obračun manje zastupljen od dekurzivnog u praksi naših banaka i uopšte u biznis praksi, u nastavku ćemo se fokusirati na dekurzivni obračun. Međutim, kako u odnosima sa ostatkom sveta anticipativni obračun kamate na kredite nije isključen, ali i zbog nekih poslovnih transakcija koje pretpostavljaju primenu anticipativnog načina kao što su menice i menični diskont, njegovo se zanemarivanje ne preporučuje. 
be worth at a later date. Hence credit must bear interest for the creditor, and the investment must bear return for the investor. Companies are investing into tangible assets (material assets that can be touched such as factories, machines, offices), and in intangible assets (patents, commodity brands, licenses). In both cases, certain money is being invested today with the expectation that more money will be earned at a later date. When the creditor is allocating money approving the borrower's request, the price of that money is the interest rate that is being calculated on the funds borrowed. Simply speaking, the interest rate is the commission ratio that we must pay in order to avail ourselves of the loan granted, divided by the amount of that loan (Rosse, 2005, p. 199). Thus the amount of interest is essentially the function of three changeable variables: money borrowed C (capital), period of capitalisation expressed in days, months or years, and the interest rate $p$. When speaking of the dependency between these variables, what is undisputable is the following: a) higher amount of principal must, under unchanged other circumstances, bring to the creditor a higher return (interest), or more precisely, the interest is directly proportional to the principal; and $b$ ) the long-term use of money is burdening the obligor with high interest rates.

\section{Characteristics of different ways to calculate interest}

From the aspect of the time in which interest is being calculated and from the aspect of the interest calculation base, there are two, essentially very different manners of calculation - decursive and anticipatory. In the first case, interest calculation and its allocation to the capital is being done at the end of every accounting period, hence, in arrear, and in the second case interest is calculated at the beginning of the accounting period on the principal from the end of the period, hence in advance.
The first case, which we are rather more familiar with in daily practice, consists of the interest upon expiry of the relevant period. Such interest is called decursive, and the accounting method a decursive one. The second case is anticipative as it anticipates that the interest is calculated at the beginning of the interest period. Such calculation is most often found in short-term credit and draft bill deals. Decursive interest rate is most often designated with the letter $p$, while the anticipative one is marked with the letter $\pi$. The following symbols are also used in interest calculation: $\mathrm{C}_{0}=$ initial value; $\mathrm{C}_{\mathrm{n}}=$ final value; $n=$ number of periods; $\mathrm{k}=$ interest. For purpose of easier understanding of the problem let us analyze the following hypothetical case:

Company was granted a loan of 1,000 dinars at an interest rate of $11 \%$ per annum. Company will pay, according to decursive calculation methods, by the end of the year, 110 dinars of interest. When applying the anticipative method of calculation the same amount of 110 dinars is obtains which will be deducted from the principal at the moment of taking the loan, and will actually use only 890 units of capital. In other words: for a completely identical service (loan) company will pay to the bank the same compensation but even one whole year earlier if the interest is calculated according to the anticipatory method. In this context, the question is raised whether $p$ is decursive interest rate equivalent to the anticipatory interest rate $\pi$ at the annual level? The two interest rates, each one of them with their own period of capitalisation, will be equivalent if they yield on the same principal and over the same period, the same interest bearing value. Let us start from 


\section{Kamatni računi i njihove karakteristike}

Fundamentalna kategorija u ovoj oblasti, oko koje se uopšte može dogovarati, je oblik zavisnosti između vremenskog perioda i iznosa kamate. To je uglavnom razlog za izbor jedne od dve moguće alternative. Prva, iz koje proizilazi prosti kamatni račun je sledeća: kamata se u svim obračunskim periodima obračunava na isti iznos (početnu glavnicu), bez obzira koliko takvih perioda protekne, dug je nastao za povraćaj novca. Ovo je najjednostavniji način da se objasni kamata, tipično za klasičnu štednju i druge kratkoročne poslove. Za raziku od prostog, osnovu za složeni kamatni račun čini kapitalizacija kamata, kamata se obračunava u svakom obračunskom periodu na sve veću glavnicu, odnosno, na početnu glavnicu uvećanu za iznos kamate iz prethodnog perioda. Zbog ovakvog povećanja glavnice iz perioda $\mathrm{u}$ period, iznosi kamate primenom složenog kamatnog računa su veći od kamata koje daje prost kamatni račun.

\section{Princip ekvivalencije kapitala}

Pojam kapitalizacije u praksi se komplikuje zbog različitih varijanti zadatih kamatnih stopa (propisanih, ugovorenih ili dogovorenih). Nezavisno od toga koji od mogućih načina primenjujemo (prosti ili složeni kamatni račun, dekurzivni ili anticipativni obračun, godišnje ili češće kapitalizacije), očito je da se dve glavnice sa različitim rokovima dospeća ili datumima valute ne mogu direktno upoređivati. Međutim, da bi ih učinili uporedivim neophodno je da ih svedemo na zajednički rok. Princip ekvivalencije kapitala kaže da u nekom trenutku, vrednost svih isplata kreditora mora biti jednaka vrednosti svih uplata dužnika, uzimajući u obzir određeni kamatni raačun. Dakle, obračun kamata, bez obzira da li se vrši dekurzivno ili anticipativno, mora biti zasnovan na sledećim principima:

a) princip zajedničkog roka, što znači da novčani iznosi, ili druge veličine koje se koriste umesto njih, radi uporedivosti moraju biti svedeni (kamaćenjem ili diskontovanjem) na isti rok i

b) princip ekvivalencije odnosno jednakosti uplata i isplata svedenih na isti rok.

Za preračunavanje se najčešće koristi valuta dospeća jednog od iznosa. Međutim, u praksi, gde se obično radi sa više od dva iznosa, princip ekvivalencije glavnice podrazumeva da je zbir svih uplata jednak zbiru svih isplata svedenih na isti rok.

\section{Prosti kamatni račun}

Upotrebljivost prostog kamatnog računa je, objektivno govoreći, ograničena na veoma kratak vremenski period. S obzirom da dužnik na kraju godine zaista vrati glavnicu i pripadajuće kamate, sa tom sumom poverilac će raspolagati naredne godine. Dakle, bar načelno nema razloga da poverilac i u drugoj godini obračunava kamate samo od početne glavnice nego od uvećanog iznosa za kamate nastale u prethodnoj godini. U suštini poverilac bi se odrekao dela sredstava koja bi mu inače pripadala. Ono što je karakteristično za prosti kamatni račun je to da svaki period kapitalizacije poveriocu donosi jednak iznos kamate. Stoga dugovani iznos (kamata plus deo glavnice) raste kao aritmetički niz. Takav niz se naziva "aritmetički" ili aritmetička progresija. Razlog je taj što je svaki član, počev od drugog, jednak aritmetičkoj sredini susednih članova. Cela se procedura može grafički prikazati pomoću stepenika. Svaki stepenik je jednako visok, što pak znači da se mogu povezati sve pripadajuće tačke u koordinatnom sistemu i povući linija.

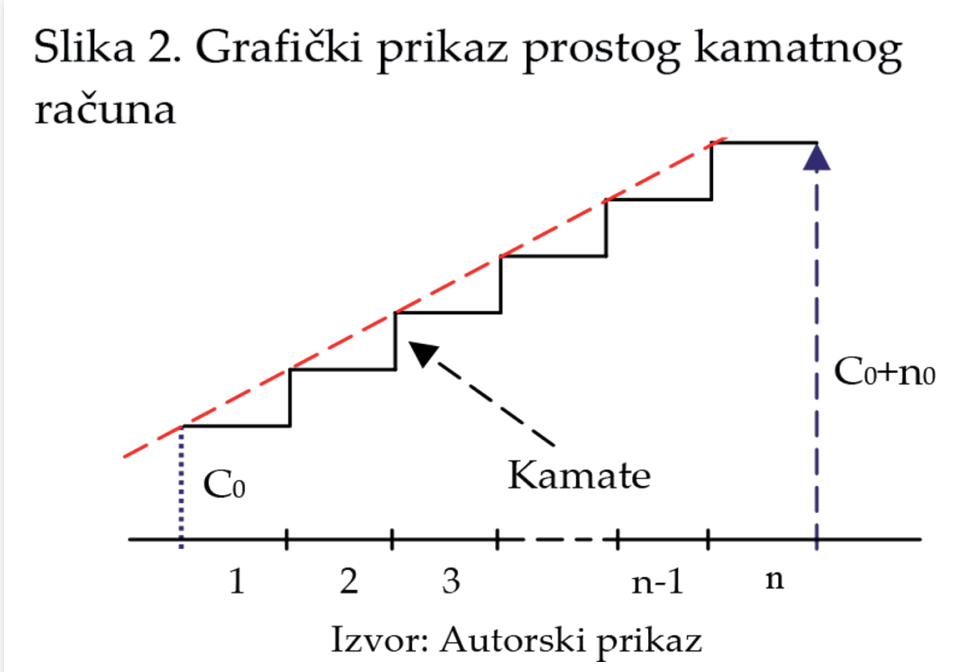


the perception of the following equivalences: two prices are equivalent if they have the same meaning and burden on the obligor, i.e. if they have the same interest/capital ratio that he has at his disposal:

1. Decursive: at the beginning of the year we had $\mathrm{C}$ monetary units and for their use, at the end of the year, we have paid Cp/100 monetary units in interest;

2. Anticipatory: at the beginning of the year we had $\mathrm{C}$ monetary units and for their use we have paid in advance: $C \pi / 100$ monetary units in interest. Hence we have the following:

$$
\frac{\mathrm{pC}}{100}: \mathrm{C}=\frac{\pi \mathrm{C}}{100}: \frac{(100-\pi) \mathrm{C}}{100} \Rightarrow \mathrm{p}=\frac{100 \pi}{100-\pi}
$$

How correct is this equation we can verify by means of data from the previous case, or even better, if we are to actively solve the equation with higher interest rates, for example, rates of $31 \%$ per annum.

$$
\mathrm{P}=\frac{100 \pi}{100-\pi}=\frac{100 \times 31}{100-31}=44,927536 \ldots \%
$$

On the basis of the result obtained we can conclude the following: $31 \%$ of anticipative interest per annum paid in advance is the equivalent to the payment of almost $45 \%$ of decursive interest. Hence the anticipative interest rate calculation with the same interest rate for the loan beneficiary is costlier than the decursive one. In view of the fact that the anticipative calculation is less present in practice of our banks than the decursive one and generally in business practice, further in this paper we shall focus on decursive calculation method. However, in the relations with the rest of the world anticipative interest rate calculation remains present, but also because of some business transactions which entail application of the anticipative method such as draft bills and draft discounts, it is not recommended that this method should be overlooked or disregarded.

\section{Interest calculations and their characteristics}

Fundamental category in this field, that can not at all be negotiated, is the form of dependence between the time period and the interest rate amount. This is mainly the reason for selection of one of the two possible alternatives. The first one, which gives a simple interest calculation, is the following: interest is being calculated in all the accounting periods on the same amount (the original principal sum invested), regardless of how many of such periods shall elapse, and the debt has incurred for the repayment of money. This is the simplest way to explain the interest, typical for the classic savings and other shortterm transactions. Contrary to this simple one, the basis for the compound interest calculation is composed of interest capitalisation where interest is calculated in every accounting period on a higher principal, i.e. on the original principal sum increased for the amount of interest from the previous period. Due to such principal increase from period to period, the amounts of interest, through the application of the compound interest calculation, are higher than the amounts resulting from the simple interest account.

\section{Capital Equivalency Principle}

The term capitalisation in practice is being complicated because of different variants of the given interest rates (prescribed, contracted or negotiated). Irrespective of which one of the possible ways we are to apply (the simple or the compound interest calculation, decursive or anticipatory calculation, annual or more frequent capitalisation), it is obvious that the two principal sums with different maturities or value dates can not be directly compared. However, in order to make them comparable, it is necessary to bring them down to a joint maturity. Capital equivalency principle says that at a certain point in time, value of all payments made by creditors must be equal to the value of all repayments effected by obligors, taking into consideration a given interest calculation. Hence, interest calculation, regardless of the fact whether it is done in decursive or anticipatory form, must be based on the following principles:

a. Principle of joint maturity, which means that monetary amounts or other magnitudes which are used in their stead, for purpose of comparability must be brought down to the same maturity (through adding interest or discounting); and 
Kamata dobijena primenom prostog kamatnog računau kontinuiranom vremenskom periodu je srazmerna početnom iznosu glavnice i periodu vremena. Ako je godišnja kamatna stopa $p \%$, iznos godišnje kamate na glavnicu C je: $\mathrm{k}=\frac{\mathrm{C} \times \mathrm{p}}{100}$. Iz načela proporcionalnosti kamate i vremena sledi da je prosta kamata za jedan mesec dvanaest puta manja od godišnje kamate, kamate za $m$ meseci su $m$ puta više nego za mesec dana, tako da u skladu s tim imamo sledeći obrazac za računanje kamate kada je vreme izraženo u mesecima: $\mathrm{k}=\frac{\mathrm{C} \times \mathrm{p} \times \mathrm{m}}{1200}$. Prosti kamatni račun se koristi za kratke vremenske periode, gde se vreme najčešće izražava u danima $(d)$. U tom smislu se jedan dan računa kao 365-ti ili 366-ti deo godine, u zavisnosti od toga da li je prosta ili prestupna godina. Analogno prethodnom, obrazac za računanje kamate za proste (prestupne) godine će imati sledeći oblik:

$\mathrm{k}=\frac{\mathrm{C} \times \mathrm{p} \times \mathrm{d}}{36500}$, odnosno, $\mathrm{k}=\frac{\mathrm{C} \times \mathrm{pxd}}{36600}$

Međutim, računanje broja dana nije savim neproblematično. Rešenja naših formula su $\mathrm{u}$ skladu sa načinom koji se $\mathrm{u}$ finansijama označava sa K, 365; što znači da smo za godinu uzeli 365 dana, (ili 366 u slučaju prestupne godine) $\mathrm{i}$ izbrojali ih precizno prema kalendaru. Korišćenje 365 dana u imeniocu u stranoj literaturi je poznato kao "exact interest" (calculation), odnosno, "exact time". Takav način je zastupljen u Kanadi i USA naročito u oblasti poslovanja poslovnih banaka sa $\mathrm{CB}$, pri trgovanju državnim obveznicama i u spoljnoj trgovini kada to zahteva strani partner. Strana ali i naša praksa poznaje dva načina koja su po nastanku starija jer potiču iz vremena kada bankari nisu mogli ni da sanjaju dostupnost univerzalnih džepnih kalkulatora a kamoli pravih kompjutera kada se smatralo korisnim zameniti nekako nespretnih 365 sa udobnijom vrednošću $360 \mathrm{u}$ imeniocu:

1. 30,360$)$ za celu godinu se uzima 360 dana, ceo mesec 30 dana;

2. K 360) - godine uvek imaju (okrugao) ceo broj, dani se broje precizno prema kalendaru.

Oba slučaja se mogu naći u literaturi pod nazivom ordinary interest, u prvom slučaju appmximate time i drugom "exact time" što verovatno nije potrebno prevoditi (Chiang, 1994,
Shao, 1986.). Način K, 360, popularno nazvan Banker's Rule predstavlja najčešće korišćeno pravilo za računanje prostih kamata u SAD. Razlike se ne mogu ignorisati, jer mogu biti nezanemarljive kada su u pitanju veliki iznosi, zato je poželjno unapred jasno definisati način obračuna kamata. Ipak, kamata obračunata na osnovu 360 umesto 365 dana, dovodi do onoga što može biti značajna razlika. Pogledajmo na konkretnom primeru.

Preduzeće se zadužilo 3. novembra 2010. za 10.000 dinara. Koliko kamata mora da plati kada 8. Februara 2011. vrati novac, ukoliko za takve kredite prosta kamatna stopa iznosi $11 \%$, primenom sva tri opisana načina?

U osnovnom obliku za obračun kamate sada moramo da razmotrimo dva moguća imenioca (36500 i 36000). Imamo i dve moguće vrednosti parametra $d$, koji predstavlja broj dana. Da bismo rešili zadatak, prvo moramo odrediti vreme. Za precizno brojanje dana (prema kalendaru) imamo: Novembar 30-3=27 (prvi dan se ne računa); Decembar 31; Januar 31; Februar 8 (poslednji dan se računa) što ukupno iznosi 97 dana. Dakle, navedenim načinom brojanja dana kamatni period je trajao 97 dana. Prema tome imamo:

$$
\begin{gathered}
\left(\mathrm{K}, 365: \mathrm{k}=\frac{\mathrm{Cpd}}{36500}=\frac{7.000 \times 11 \times 97}{36500}=204,63\right. \\
\left(\mathrm{K}, 360: \mathrm{k}=\frac{\mathrm{Cpd}}{36000}=\frac{7.000 \times 11 \times 97}{36000}=207,47\right.
\end{gathered}
$$

Kada se dani broje "okruglo" $(30-$ 3) $+30+30+8=95$, imamo:

$\left(30,360: \mathrm{k}=\frac{\mathrm{Cpd}^{*}}{36000}=\frac{7.000 \times 11 \times 95}{36000}=203,19\right.$

Na osnovu analiziranih primera, možemo dati nekoliko preporuka i zaključaka.

- Dekurzivni obračun kamata u praksi (u zemlji i inostranstvu) je znatno češći nego anticipativni, stoga se preporučuje njegova primena u svim transakcijama, ukoliko nije drukčije ugovoreno.

- Isto se odnosi na kamatnu stopu - poželjna je primena godišnje kamatne stope koja važi za celu godinu kao osnovna jedinica vremena, ako nije drukčije navedeno. U praksi, možemo da naiđemo na specifične dobro poznate oznake: p.a ("godišnje"), p.s. ("polugodišnje"), p.q ("kvartalno"), p.m. 
b. Principle of equivalency or equivalence of pay-in and pay-off brought down to the same maturity.

For calculation purposes what is most often used is the value date of one maturity amount. However, in practice where it is usually the case of two or more amounts, the principle of principal equivalency implies that the sum of all payments made is equal to the sum of all the disbursements effected for the same maturity.

\section{The simple interest calculation}

Applicability of the simple interest calculation is, objectively speaking, limited to a very short time period. In view of the fact that the obligor by the end of the year is really repaying the principal and the appurtenant interest, that will be the amount that the creditor will be able to use during the next year. Therefore, at least in principle, there is no reason for the creditor also in the second year to calculate interest only from the initial principal but from the increased amount of interest accrued during the previous year. Essentially, creditor would then be renouncing on a part of money that he would have the right to own. What is characteristic for the simple interest calculation is that every capitalisation period brings to the creditor an equal amount of interest. Hence the debenture amount (interest plus one part of principal) is growing as an arithmetic series. This series is called "arithmetic" or an arithmetic progression. The reason is that every member, starting from the other one, is equal to the arithmetic mean of the neighbouring members. The entire procedure may be graphically presented by means of a step-ladder. Every step is equally high which means that all the appurtenant points in the coordinate can be connected.
Interest obtained by the application of the simple interest calculation in a continuous time period is proportional to the initial amount of the principal and the period of time. If the annual interest rate is $p \%$, the amount of the annual interest on principal $C$ is: $k=\frac{C \times p}{100}$. What follows from the principle of interest and time proportionality is that the simple interest rate for one month is twelve times lower than the annual interest, the interests for $m$ months are $m$ times higher than those for one month, so that in this respect we have the following formulas for calculating interest when time is expressed in months: $\mathrm{k}=\frac{\mathrm{C} \times \mathrm{pxm}}{1200}$. The simple interest calculation is used for short-term time periods when time is most often expressed in days (d). In this respect, one day is calculated as 365th or 366th part of the year, depending on whether it is an ordinary or a leap year. Analogy to the previously stated is the formula for calculating interest for the simple (leap) year that will have the following form:

$\mathrm{k}=\frac{\mathrm{C} \times \mathrm{pxd}}{36500}$, i.e. $\mathrm{k}=\frac{\mathrm{C} \times \mathrm{pxd}}{36600}$

However, calculation of the number of days is not quite devoid of its problems. The solutions of our equations are in concordance with the manner which is in finances designated with $K, 365$, which means that we have taken into account a year of 365 days (or 366 days in case of a leap year) and have counted them out precisely according to the annual calendar. The application of 365 days in the nominator is known in foreign literature as the "exact interest" (calculation), i.e. "exact time". Such a 
("mesečno") i konačno p.d. ("dnevno").

- Sve međufazne obračune treba sprovoditi detaljno, koliko nam mogućnosti dopuštaju, uz smisleno zaokruživanje konačnih rezultata, pre svega iznosa (uobičajeno na dva decimalna mesta).

- Navedeno za brojanje dana vredi i za složeni kamatni račun, bar u našim uslovima gde se takvo računanje vremena dosledno meri u danima i tačno prema kalendaru, uzimajući u obzir čak i prestupne godine.

Mi ćemo u nastavku koristiti isključivo način (K, 365), s tim da moramo biti svesni činjenice da se u praktičnoj primeni najčešće greške odnose upravo na pogrešno utvrđeni broj dana. Izračunati jednu od nepoznatih veličina na osnovu prethodnih obrazaca, verovatno ne predstavlja poseban problem, tako da se detaljnim postupkom nećemo baviti. Umesto toga, pokažimo, kako izračunati vrednosti ostalih parametara u slučaju kada je poznata uvećana vrednost glavnice, ali ne i njena osnovna veličina.

Pretpostavimo da je poznata kamatna stopa $p$, uvećana glavnica $\mathrm{C}^{+}=\mathrm{C}+\mathrm{k}$, kao i kamatni period, i da želimo da izračunamo osnovni iznos glavnice C i kamatu k. Postupak je prikazan za vreme izraženo u danima a ostale verzije dobijamo zamenom imenioca $u$ osnovnom obrascu:

$$
\begin{aligned}
& C^{+}=C+\frac{C \times p \times d}{36500+p \times d}=C \frac{36500+p \times d}{36500} \\
& C=\frac{36500 \times C^{+}}{36500+p \times d}
\end{aligned}
$$

Iznos kamata ćemo dobiti tako što ćemo glavnicu pomnožiti sa proizvodom $p$ i $d$ i podeliti sa 36500. Iz obrasca možemo izvesti formulu za direktno računanje kamata ako je poznata

$C^{+}: k=\frac{C^{+} \times p \times d}{36500+p \times d}$

O prikazanom postupku takođe treba reći i to da direktno računanje kamata nikad nije suvišno, jer time izbegavamo greške koje mogu biti nasleđene usled pogrešno izračunate vrednosti C. Općenito, pokušajmo sve nepoznanice izračunati direktno na bazi ulaznih podataka. Za ilustraciju poslužiče sledeći primer.
Preduzeće je zajedno sa obračunatim zateznim kamatama po stopi od $11 \%$ p.a. vratilo 22.946,28 dinara. Koliko je iznosio dugovani iznos a koliko zatezne kamate ako je kasnilo sa plaćanjem 36 dana?

Ako je

$\mathrm{C}^{+}=22.946,28 ; \mathrm{p}=11 \% ; \mathrm{d}=36$ imamo:

$$
\mathrm{C}=\frac{36500 \times \mathrm{C}^{+}}{36500+\mathrm{p \times d}}=\frac{36500 \times 22.946,28}{36500+11 \times 36}=22.700,00
$$

i

$\mathrm{k}=\frac{\mathrm{C}^{+} \times \mathrm{p} \times \mathrm{d}}{36500+\mathrm{p} \times \mathrm{d}}=\frac{22.946,28 \times 11 \times 36}{36500+11 \times 36}=246,28$

Ipak, $k$ smo mogli brže dobiti pomoću obrasca $C^{+}-\mathrm{C}=(22.946,28-22.700,00=246,28)$.

Ostale dve nepoznanice $p$ i $d$ možemo izračunati bez rešavanja prethodnih jednačina. U tom slučaju moraju biti poznate kako osnovna tako i uvećana glavnica (ili jedna od njih i iznos kamata). Kao što se može primetiti, kod anticipativnog obračuna računanje početne glavnice nije komplikovano, jer jednostavno oduzmemo kamate od konačne vrednosti glavnice koja predstavlja osnovicu za njihov obračun. Zahtevniji deo posla je pak računanje konačne vrednosti iz date početne glavnice. Pogledajmo na konkretnom primeru:

Pretpostavimo da je poznata anticipativna kamatna stopa $\pi$, umanjena glavnica $\mathrm{C}^{-}=\mathrm{C}-\mathrm{k}$, kamatni period $d$, i da želimo da izračunamo konačni iznos glavnice $C$ i kamate $k$. Postupak ćemo ponovo prikazati samo za vreme izraženo u danima, ostale varijable možemo da dobijemo ako zamenimo imenilac u osnovnom obrascu:

$$
\begin{aligned}
& C^{-}=C-\frac{C \times \pi \times d}{36500}=C \frac{36500-\pi \times d}{36500} \\
& \Rightarrow C=\frac{36500 \times C^{-}}{36500-\pi \times d}
\end{aligned}
$$

Anticipativna kamata za $d$ dana je jednaka $\mathrm{k}=\frac{\mathrm{C} \pi \mathrm{d}}{36500}$, odnosno, $\mathrm{k}=\frac{\mathrm{C} \times \pi_{\mathrm{xd}}}{36500-\pi \mathrm{xd}}$.

Preduzeću je odobren anticipativni kredit sa rokom otplate od 89 dana uz prostu kamatnu stopu $\pi=11 \%$; p.a. Koliko je iznosio posuđeni iznos ako je po zaključenju ugovora plaćeno 17.127.934,25 dinara?

$\mathrm{C}=\frac{36500 \times \mathrm{C}^{-}}{36500-\pi \times \mathrm{d}}=\frac{36500 \times 17.127 .934,25}{36500-11 \times 89}=17.600 .000,00$ 
manner of calculation is to be found in Canada and the USA especially in the field of operations of the business banks with the $\mathrm{CB}$, in the trading in treasury bonds and in foreign trade, and when so requested by the foreign partner. The foreign but also our own practice recognises two ways which are in their origin senior as they originate from the time when bankers could not even dream of gaining access to the universal pocket calculators, let alone to real computers, and when it was deemed useful to replace those, somehow awkward 365 with a much more comfortable value of 360 in the nominator:

1. $(30,360)$ - For the entire year the number of 360 days is taken into account, and 30 days for the entire month;

2. (K 360) - Years are always having (rounded up) an integer number and days are counted precisely according to the calendar.

Both of these cases may be found in literature under the name ordinary interest, in the first case it is the approximate time, and in the other the exact time, which is probably not necessary to translate (Chiang, 1994, Shao, 1986). The K 360 manner broadly known as the Banker's Rule is the most often used rule for calculating single interest rates in the USA. The differences, however, can not be ignored as they may not be negligible when speaking of large amounts, so it is rather useful to define clearly and in advance the manner of calculation of the interest rates. Nevertheless, interest calculated on the basis of 360 days instead of 365 days brings about something that may become a significant difference. Let us see this situation on a concrete example.

The company on 3 November 2010 borrowed 10,000 dinars. How much interest is the company to pay when on 8 February 2011 it has repaid its debt, if for such loans the simple interest rate is $11 \%$, with the application of all of the three described manners?

In the basic form for interest calculation we must now consider two possible nominators (36500 and 36000). We have also two possible values of the parameter $d$, which designates the number of days. In order to do our math, firstly we must determine the time. For precise calculation of days (according to the calendar), we have the following: November 30-3-27 (the first day is not calculated); December 31st; January 31st; February 8th (the last day is not calculated) which makes up for a total of 97 days. Therefore, according to the above stated manner of calculation of days the interest period lasted for 97 days. Hence we have the following:

$$
\begin{gathered}
\left(\mathrm{K}, 365: \mathrm{k}=\frac{\mathrm{Cpd}}{36500}=\frac{7.000 \times 11 \times 97}{36500}=204,63\right. \\
\left(\mathrm{K}, 360: \mathrm{k}=\frac{\mathrm{Cpd}}{36000}=\frac{7.000 \times 11 \times 97}{36000}=207,47\right.
\end{gathered}
$$

When days are counted as "rounded up" $(30-3)+30+30+8=95$, we have

$$
\left(30,360: \mathrm{k}=\frac{\mathrm{Cpd}^{*}}{36000}=\frac{7.000 \times 11 \times 95}{36000}=203,19\right.
$$

On the basis of the examples analysed we can give several recommendations and make some conclusions:

- Decursive interest calculation method in practice (both in the country and abroad) is much more often to be found than the anticipative one, hence it is recommended to have it applied on all transactions, if not otherwise contracted.

- The same applies to the interest rate - it is more opportune to apply the annual interest rate which is valid for the entire year as the basic unit of time, if not otherwise contracted. In practice, we may encounter some specific well known designation marks: p.a. ("per annum"), p.s. ("per semiannum"), p.q. ("per quarter"), p.m. ("per month"), and finally p.d. ("per day").

- All the inter-phase calculations should be conducted in detail, as far as the circumstances would allow, with a mindful rounding up of the final results, first of all the total sums (usually, on to the two decimal places).

- The above mentioned calculation of days applies also to the complex interest calculation, at least in our circumstances where such calculation of time is consistently measured in days and precisely according to the calendar, taking into account even the leap years.

Further here in this paper we shall use exclusively the $(K, 365)$ method, but we must be aware of the fact that in practical application 
Anticipativna kamata je u ovom slučaju iznosila 472.065,75 dinara, (17.600.000,0017.127.934,25). Poređenja radi, lako možemo izračunati dekurzivne kamate uz kamatnu stopu od $11 \%$ za 89 dana na iznos od 17.127.934,25 dinara i ustanoviti da postoji razlika između kamata od nekoliko hiljada dinara. Radi ilustracije postupka iznalaženja ostalih nepoznatih veličina oblikovana su sledeća tri primera:

1. koliko iznosi kamata na zajam od $71.000,00$ dinara na rok od 57 dana, $\mathrm{p}=5 \%$, uz dekurzivni obračun, godišnju kapitalizaciju i prosti kamatni račun?

$$
\mathrm{k}=\frac{\mathrm{C} \times \mathrm{p} \times \mathrm{d}}{36500}=\frac{71.000 \times 5 \times 57}{36500}=554,38
$$

2. kolika je diskontovana vrednost glavnice od 2.100.000,00 dinara koja dospeva nakon 119 dana, ako je godišnja kamatna stopa $13 \%$, prost kamatni račun i dekurzivni obračun?

$$
\begin{aligned}
& C=\frac{36500 \times C^{+}}{36500+p \times d} \\
& \Rightarrow C=\frac{36500 \times 2.100 .000}{36500+13 \times 119}=2.014 .613,50
\end{aligned}
$$

3. kolika je diskontovana vrednost glavnice od 2.100.000,00 dinara koja dospeva za 119 dana, ako je godišnja kamatna stopa $13 \%$, prost kamatni račun i anticipativni obračun?

$$
\begin{aligned}
& \mathrm{C}^{-}=\mathrm{C}-\mathrm{k}=\mathrm{C}-\frac{\mathrm{C} \times \pi \times \mathrm{d}}{36500} \\
& \mathrm{C}^{-}=2.100 .000-\frac{2.100 .000 \times 13 \times 119}{36500}=2.010 .994,52
\end{aligned}
$$

Termin "diskontovana vrednost" se u poslovnim finansijama dosledno koristi na način vidljiv iz prethodnih primera: označava sadašnju vrednost budućih novčanih primitaka. Temelji se na vremenskoj vrednosti novca i činjenici da isti iznos novca u sadašnjosti i u budućnosti nema istu vrednost. Iako se u većini slučajeva diskontovanje sprovodi složenim kamatnim računom, za kratkoročne poslove takođe moramo ovladati prikazanim načinom diskontovanja. Na primer, dekurzivnim načinom određujemo potrebnu visinu depozita koji će nam kroz određeno vreme doneti željeno konačno stanje uloga a anicitipativno obračunavamo menični diskont $\mathrm{i}$ dobijamo diskontovanu vrednost menice.

\section{Složeni kamatni račun}

Pojam složene kamate može se upotrebiti za rešavanje mnogobrojnih problema $u$ finansijama (Van Horne, 2002. p. 39). Kamata se pripisuje glavnici i time formira nova glavnica. Otuda naziv kamatno kamatni račun, u kojem kamate daju nove kamate. Sam postupak pripisivanja kamate glavnici i formiranje nove glavnice naziva se kapitalizacija a razmak između dve kapitalizacije period kapitalizacije. Broj kapitalizacija u jednoj godini odnosno, perioda za koji je data kamatna stopa najčešće se obeležava sa M. Ovaj postupak ćemo ilustovati na konkretnom primeru:

Pretpostavimo da početna glavnica $\mathrm{C}_{0}$ ima $n$ perioda i da se obračunava složena kamata po stopi od $p \%$ za period. Serijska stanja na kraju svakog perioda dobićemo pomoću sledećih razmatranja:

$$
\mathrm{C}_{1}=\mathrm{C}_{0}+\frac{\mathrm{C}_{0} \times \mathrm{p}}{100}=\mathrm{C}_{0}\left(1+\frac{\mathrm{p}}{100}\right)=\mathrm{C}_{0} \mathrm{r}
$$

Ovde je sa $r=1+p / 100$ označen diskontni faktor. Osnovica za obračun kamate u drugoj godini je glavnica do kraja prve godine, koja već sadrži kamatu iz prve godine. To nam daje:

$$
\mathrm{C}_{2}=\mathrm{C}_{1}+\frac{\mathrm{C}_{1} \mathrm{p}}{100}=\mathrm{C}_{1}\left(1+\frac{\mathrm{p}}{100}\right)=\mathrm{C}_{1} \mathrm{r}=\left(\mathrm{C}_{0} \mathrm{r}\right) \mathrm{r}=\mathrm{C}_{0} \mathrm{r}^{2}
$$

Nakon $n$ godina, naravno, ako je kamatna stopa ista, stanje glavnice možemo dobiti pomoću sledeće jednačine:

$$
\mathrm{C}_{\mathrm{n}}=\mathrm{C}_{0}\left(1+\frac{\mathrm{p}}{100}\right)^{\mathrm{n}}=\mathrm{C}_{0} \mathrm{r}^{\mathrm{n}}
$$

Ovo je osnovni obrazac složenog kamatnog računa, koji povezuje početnu i konačnu glavnicu, broj kamatnih perioda i (kroz diskontni faktor) kamatne stope. Za ilustraciju postupka poslužiće sledeći primer.

Koliko ćemo imati u banci nakon 5 godina ako danas uložimo 5.000.000,00 dinara, pri godišnjoj kapitalizaciji i dekurzivnom obračunu kamata ako je kamatna stopa: a) $p=6 \%$ i za $50 \%$ veća b) $p=9 \%$ ?

Koristićemo opšti obrazac za računanje složene kamate:

$$
C_{n}=C_{0} r^{n}=5.000 .000 \times 1,06^{5}
$$

$C_{n}=5.000 .000 \times 1,33822558=6.691 .127,89$ 
the most frequent errors pertain actually to an erroneous determination of the number of days. To calculate one of the unknown values on the basis of the previous formats most probably does not pose a great problem, so that we will not engage in more detailed analysis of the procedure. Let us demonstrate, instead, how to calculate the values of other parameters in the case when we know the increased value of principal amount, but not its basic, original size.

Let us assume that the interest rate $p$ is known, increased principal $\mathrm{C}^{+}=\mathrm{C}+\mathrm{k}$, and also the interest period, and that we wish to calculate the basic amount of the principal C and the interest $\mathrm{k}$. The procedure is presented for the time expressed in days, and the other versions we obtain by changing the nominator in the basic formula:

$$
\begin{aligned}
& C^{+}=C+\frac{\mathrm{C} \times \mathrm{p} \times \mathrm{d}}{36500+\mathrm{p} \times \mathrm{d}}=\mathrm{C} \frac{36500+\mathrm{p} \times \mathrm{d}}{36500} \\
& \mathrm{C}=\frac{36500 \times \mathrm{C}^{+}}{36500+\mathrm{p} \times \mathrm{d}}
\end{aligned}
$$

The amount of interest we will obtain by multiplying the principal with the product of $p$ and $d$ and divide it with 36500. From the equation we can draw a formula for direct calculation of the interest, if we know the

$$
\mathrm{C}^{+}: \mathrm{k}=\frac{\mathrm{C}^{+} \times \mathrm{p} \times \mathrm{d}}{36500+\mathrm{p} \times \mathrm{d}}
$$

What should also be said about the presented procedure is that direct calculation of interest is never superfluous as it offers the way to avoid errors that may be inherited from erroneously calculated $C$ value. Generally speaking, let us try to calculate directly all the unknowns on the basis of the input data. For illustration we shall offer the following example:

The company has repaid 22,946.28 dinars together with the calculated interest on arrears at the rate of $11 \%$. What was the amount of debt, and what was the amount of interest if the company was defaulting on repayment for 36 days?

If $\mathrm{C}^{+}=22,946.28 ; \mathrm{p}=11 \% ; \mathrm{d}=36$ we have the following:

$$
\mathrm{C}=\frac{36500 \times \mathrm{C}^{+}}{36500+\mathrm{p} \times \mathrm{d}}=\frac{36500 \times 22.946,28}{36500+11 \times 36}=22.700,00
$$

and

$\mathrm{k}=\frac{\mathrm{C}^{+} \times \mathrm{p} \times \mathrm{d}}{36500+\mathrm{p} \times \mathrm{d}}=\frac{22.946,28 \times 11 \times 36}{36500+11 \times 36}=246,28$

Nevertheless, we could have obtained $k$ faster by means of the equation $\mathrm{C}^{+}-\mathrm{C}=(22,946.28$ $22,700.00=246.28)$.

The other two unknown $p$ and $d$ can be calculated without solving previous equations. In that case what must be known are both the basic and the increased principal (or one of them and the amount of interest). It may be noted that in anticipative calculation, counting of the original principal is not complicated, because we simply subtract interest from the final value of the principal which presents the basis for their calculation. More demanding part of work is calculation of the final value from the given original principal. Let us see the following example:

If we assume that the known values are anticipative interest rate $\pi$, decreased principal $\mathrm{C}^{-}=\mathrm{C}-\mathrm{k}$, interest period $d$, we want to calculate the final amount of principal $C$ and interest $k$. We shall present again the procedure only for the time expressed in days, while the other variables we can obtain if we replace nominator in the basic formula:

$$
\begin{aligned}
& C^{-}=C-\frac{C \times \pi \times d}{36500}=C \frac{36500-\pi \times d}{36500} \Rightarrow C=\frac{36500 \times C^{-}}{36500-\pi \times d} \\
& \Rightarrow C=\frac{36500 \times C^{-}}{36500-\pi \times d}
\end{aligned}
$$

Anticipative interest for $d$ days is equal to

$$
k=\frac{C \pi d}{36500} \text {, i.e. } k=\frac{C \times \pi x d}{36500-\pi \times d}
$$

The company was granted anticipative loan with the repayment maturity of 89 days with the simple interest rate $\pi=11 \%$; p.a. What was the amount borrowed if upon concluding credit agreement the amount of $17,127,934.25$ dinars was paid?

$\mathrm{C}=\frac{36500 \times \mathrm{C}^{-}}{36500-\pi \times \mathrm{d}}=\frac{36500 \times 17.127 .934,25}{36500-11 \times 89}=17.600 .000,00$

Anticipative interest in this case amounted to 472,065.75 dinars, (17,600,000.00-17,127,934.25). For purpose of comparison, we can easily calculate decursive interest with the interest rate of $11 \%$ for 89 days on the amount of $17,127,934.25$ 


$$
\mathrm{C}_{\mathrm{n}}=\mathrm{C}_{0} \mathrm{r}^{\mathrm{n}}=5.000 .000 \times 1,09^{5}
$$

\section{$\mathrm{Cn}=5.000 .000 \times 1,538624=7.693 .119,77$}

U prvom slučaju, diskontni faktor je 1,06 a u drugom 1,09; pete potencije ova dva faktora su: $1,06^{5}=1,33822558$ i $1,09^{5}=1,538624$, što znači da imamo: a) konačna glavnica 6.691.127,89 dinara, kamata 1.691.127,89 dinara. U drugom slučaju b) konačna glavnica 7.693.119,77 dinara, kamata 2.693.119,77 dinara. Količnik kamata je 1,59.

De facto, pri povećanju kamatne stope za $50 \%$, dobijamo povećanje kamate veće od $59 \%$. To je u svakom pogledu značajna razlika u odnosu na prosti kamatni račun gde su kamate direktno proporcionalne kamatnoj stopi. Dakle, važi pravilo: Čim se kamata primenom složenog kamatnog računa obračunava najmanje dva perioda, procenat povećanja kamata premašuje procenat povećanja kamatne stope.

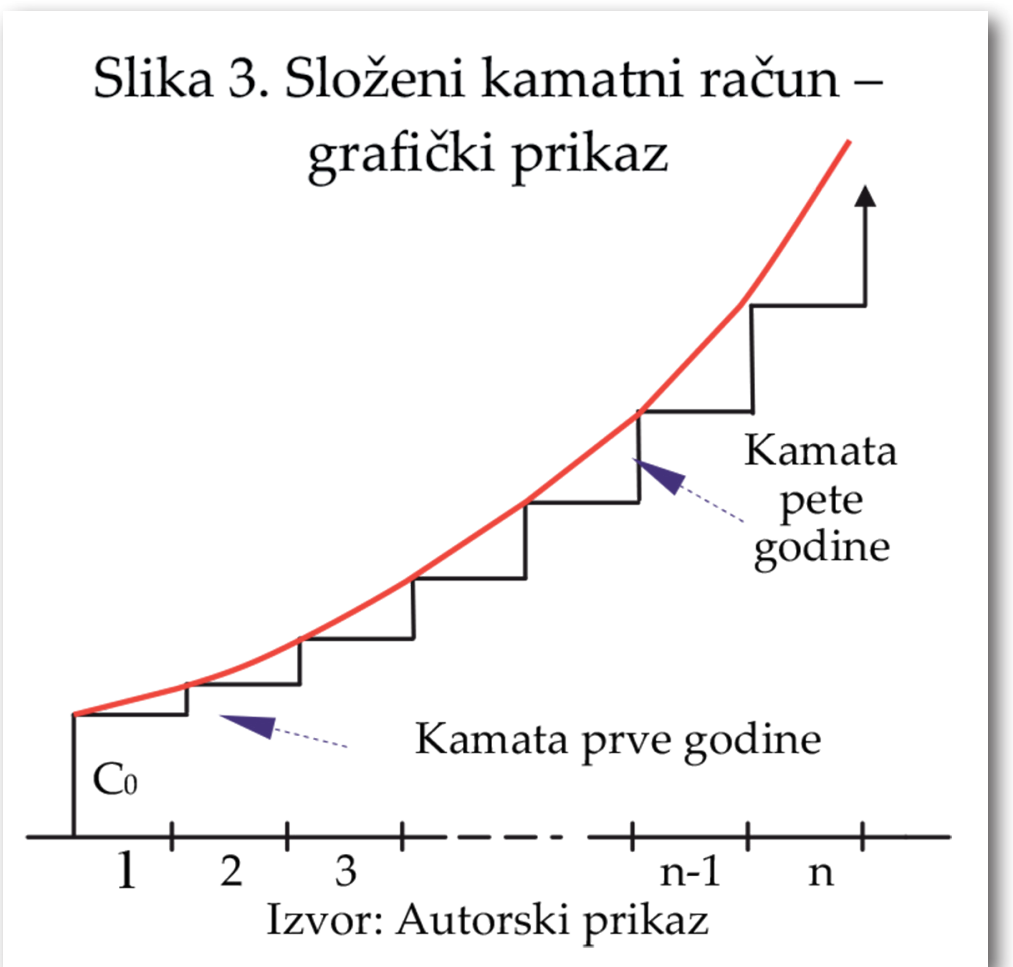

od nepoznanica, ukoliko su poznate ostale tri:

a) početnu glavnicu iznalazimo koristeći primarna znanja: $\mathrm{C}_{\mathrm{n}}=\mathrm{C}_{0} \mathrm{r}^{\mathrm{n}} \Rightarrow \mathrm{C}_{0}=\frac{\mathrm{C}_{\mathrm{n}}}{\mathrm{r}^{\mathrm{n}}}$

Postavimo sledeći primer.

Koliko treba da uložimo u banku da bi uz kamatnu stopu od 7\% i godišnju kapitalizaciju nakon 12 godina, imali 1.000.000,00 dinara?

$\mathrm{C}_{0}=\frac{\mathrm{C}_{\mathrm{n}}}{\mathrm{r}^{\mathrm{n}}}=\frac{1.000 .000}{1,07^{12}}=444.011,96$ dinara.

b) Kamatne stope možemo da izračunamo tako što ćemo prethodno izračunati nepoznati diskontni faktor, a na osnovu njega u skladu sa definicijom diskontnog faktora lako možemo da dobijemo kamatnu stopu tako da faktor $r$ umanjimo za 1 , a decimalni zarez pomerimo za dva mesta u desno.

$$
C_{n}=C_{0} r^{n} \Rightarrow r^{n}=\frac{C_{n}}{C_{0}} \Rightarrow r=\sqrt[n]{\frac{C_{n}}{C_{0}}}
$$

Primer: Preduzeće je u banku je uložilo 31.000.00 dinara, a nakon pet godina je dobilo obaveštenje da je pripisan iznos od 14.549,93 dinara na ime kamate. Po kojoj kamatnoj stopi su obračunate kamate ako je banka koristila složeni kamatni račun i godišnju kapitalizaciju?

Najlakši način da se izračuna visina kamatne stope je da se na osnovu početne glavnice i kamate izračuna konačna glavnica pomoću sledećeg obrasca:

$$
\begin{aligned}
& r=\sqrt[n]{\frac{C_{n}}{C_{0}}}=\sqrt[5]{\frac{31.000,00+14.549,93}{31.000,00}} \\
& r=\sqrt[5]{1,46935258}=1,0800036 \ldots
\end{aligned}
$$

što nakon zaokruživanja

Osnovni obrazac složenog kamatnog računa pokazuje da se glavnica povećava kao geometrijski niz, što odgovara neprekidnom eksponencijalnom rastu. Važno je uočiti da se $\mathrm{u}$ ovom slučaju ne radi samo o "stepeništu u usponu", veći o povećavanju nivoa pojedinačnih stepenika, kao osnovice za obračun kamate. Iznos kamate se iz godine u godinu povećava. $\mathrm{Na}$ osnovu osnovnog obrasca složenog kamatnog računa možemo izračunati bilo koju pokazuje da je godišnja kamatna stopa tačno $8 \%$. c) Nešto zahtevnije je računanje vremena. Pogledajmo kako to izgleda na konkretnom primeru.

Koliko je vremena potrebno da se glavnica udvostruči, ako je godišnja kamatna stopa $8 \%$, kapitalizacija godišnja i dekurzivni obračun? Udvostručavanje znači da je $\mathrm{C}_{\mathrm{n}}=2 \mathrm{C}_{0}$, kamatni faktor je 1,08, tako da imamo: 
dinars and determine that there is a difference between the interests of some several thousand dinars. For purpose of illustration of procedure for finding the other unknown values, the following three examples are given:

1. How high is the interest on a loan of $71,000.00$ dinars granted for a period of 57 day, $p=5 \%$, with decursive calculation applied, annual capitalisation and the simple interest account?

$$
\mathrm{k}=\frac{\mathrm{C} \times \mathrm{p} \times \mathrm{d}}{36500}=\frac{71.000 \times 5 \times 57}{36500}=554,38
$$

2. What is the amount of discounted value of principal of 2,100,000.00 dinars which matures after 119 days if the annual interest rate is $13 \%$, simple interest account and decursive calculation method?

$$
\begin{aligned}
\mathrm{C} & =\frac{36500 \times \mathrm{C}^{+}}{36500+\mathrm{p} \times \mathrm{d}} \\
& \Rightarrow \mathrm{C}=\frac{36500 \times 2.100 .000}{36500+13 \times 119}=2.014 .613,50
\end{aligned}
$$

3. What is the amount of the discounted value of principal of 2,100,000.00 dinars which matures in 119 days, if the annual interest rate is $13 \%$, simple interest account and the anticipatory calculation method?

$$
\begin{aligned}
& \mathrm{C}^{-}=\mathrm{C}-\mathrm{k}=\mathrm{C}-\frac{\mathrm{C} \times \pi \times \mathrm{d}}{36500} \\
& \mathrm{C}^{-}=2.100 .000-\frac{2.100 .000 \times 13 \times 119}{36500}=2.010 .994,52
\end{aligned}
$$

The term "discounted value" in business finances is consistently used in the manner shown in the previous examples: it designates present value of future cash flows. It is based on the time value of money and the fact that the same amount of money at present and in the future will not have the same value. Although in most cases discounting is conducted through complex interest account, for the short-term deals we must also master the presented manner of discounting. For example, we use the decursive method to determine necessary amount of deposit which will bring us through a certain period of time the desired final balance of the deposit, while the anticipatory calculation we use to calculate monthly discount and to obtain the discounted value of the draft bill.

\section{Compound Interest calculation}

The term compound interest may be used for resolving numerous problems in finances (Van Horne, 2002, p.39). Interest is ascribed to the principal and thus a new principal is formed. Hence the name compound interest calculation in which interests yield new interests. The procedure itself of ascribing interest to the principal and formation of the new principal is called capitalisation, and the interval between two capitalisations is called capitalisation period. Number of capitalisations in one year, i.e. periods for which the interest rate is given is most often designated with a letter M. We shall illustrate this procedure through a concrete example:

Let us assume that the initial principal $C_{0}$ has $n$ periods and that the compound interest is calculated at the rate of $p \%$ per period. Serial balances at the end of each period we shall obtain by means of the following deliberations:

$$
\mathrm{C}_{1}=\mathrm{C}_{0}+\frac{\mathrm{C}_{0} \times \mathrm{p}}{100}=\mathrm{C}_{0}\left(1+\frac{\mathrm{p}}{100}\right)=\mathrm{C}_{0} \mathrm{r}
$$

In this case $r=1+p / 100$ designates discounting factor. The basis for interest calculation in the second year is the principal up to the end of the first year, which already contains the interest from the first year. This gives us the following:

$$
\mathrm{C}_{2}=\mathrm{C}_{1}+\frac{\mathrm{C}_{1} \mathrm{p}}{100}=\mathrm{C}_{1}\left(1+\frac{\mathrm{p}}{100}\right)=\mathrm{C}_{1} \mathrm{r}=\left(\mathrm{C}_{0} \mathrm{r}\right) \mathrm{r}=\mathrm{C}_{0} \mathrm{r}^{2}
$$

After $n$ years, of course, if the interest rate remains the same, the balance of the principal may be obtained by means of the following equation:

$\mathrm{C}_{\mathrm{n}}=\mathrm{C}_{0}\left(1+\frac{\mathrm{p}}{100}\right)^{\mathrm{n}}=\mathrm{C}_{0} \mathrm{r}^{\mathrm{n}}$

This is the basic format of the compound interest calculation, which links the original and the final principal, the number of interest periods and (through the discounting factor) the interest rates. For illustration of this procedure we offer the following example:

How much money will we have in the bank after 5 years if we are to deposit today the amount of 5,000,000.00 dinars, at an annual capitalisation and decursive interest calculation, if the interest rate is: a) $p=6 \%$ and for $50 \%$ high b) $p=9 \%$ ? 


$$
\begin{aligned}
& \mathrm{C}_{\mathrm{n}}=\mathrm{C}_{0} \mathrm{r}^{\mathrm{n}} \Rightarrow \\
& \log \mathrm{C}_{\mathrm{n}}=\log \mathrm{C}_{0}+\mathrm{n} \log \mathrm{r} \Rightarrow \mathrm{n}=\frac{\log \mathrm{C}_{\mathrm{n}}-\log \mathrm{C}_{0}}{\log \mathrm{r}} \\
& \mathrm{n}=\frac{\log 2 \mathrm{C}_{0}-\log \mathrm{C}_{0}}{\log \mathrm{r}}=\frac{\log 2}{\log 1,08}=9,006468342
\end{aligned}
$$

Na osnovu dobijenog rezultata možemo da zaključimo da će se pri kamatnoj stopi od $8 \%$ glavnica udvostručiti za devet godina.

\section{Relativna i konformna kamatna stopa}

Tokom perioda visokih kamatnih stopa $\mathrm{u}$ praksi se primenjuje pravilo skraćenja perioda godišnje kapitalizacije na ispodgodišnju, da bi knjigovodstveno stanje duga bilo što je moguće bliže stvarnom stanju. $S$ tim u vezi javlja se problem kako, odnosno, sa kojom kamatnom stopom pripisati kamate za takve (kraće ili duže) vremenske periode. Postoje dve mogućnosti koje nas dovode do pojmova relativne i konformne kamatne stope. Za dati period kapitalizacije dobćemo relativnu kamatnu stopu tako što ćemo godišnju kamatnu stopu podeliti sa brojem $\mathrm{M}$, koji govori koliko puta je period kapitalizacije kraći od godine dana. Tako je polugodišnja kamatna stopa polovina godišnje kamatne stope, kvartalna četvrtina, mesečna dvanaestina, a dnevna 1/365 ili 1/366 za prestupnu godinu. Ovaj postupak je očigledno vrlo jednostavan ali ne $i$ sasvim ispravan. Doslednom primenom relativne kamatne stope uz ispodgodišnju kapitalizaciju dobijemo veće konačne vrednosti glavnice od vrednosti koju bi dobili primenom godišnje kamatne stope $p$ uz godišnju kapitalizaciju. Radi lakšeg razumevanja problema, analizirajmo sledeći primer.

Proverimo da li će konačna vrednost dobijena primenom nominalne i relativne kamatnne stope biti ista ili ne. Kolike su razlike između vrednosti glavnice od 100 novčanih jedinica po isteku jedne godine uz godišnju, polugodišnju, kvartalnu i mesečnu kapitalizaciju primenom

\begin{tabular}{|l|r|r|r|r|}
\hline \multirow{2}{*}{ k. stopa } & \multicolumn{4}{|c|}{ kapitalizacija } \\
\cline { 2 - 5 } & godišnja & $\begin{array}{l}\text { polu- } \\
\text { godišnja }\end{array}$ & kvartalna & mesečna \\
\hline $11 \%$ p.a & 111,00 & 111,30 & 111,46 & 111,57 \\
\hline $110 \%$ p.a. & 210,00 & 240,25 & 264,27 & 286,47 \\
\hline
\end{tabular}

relativne kamatne stope gde je godišnja kamatna stopa: a) $\mathrm{p}=11 \%$ i b) $\mathrm{p}=110 \%$ ?

Razlike se očigledno povećavaju sa povećanjem kamatne stope i češćom kapitalizacijom. Za kamatnu stopu $\mathrm{p}=11 \%$ i godišnju kapitalizaciju kamatni faktor je $1+11 / 100=1,11$. Kamatni faktor koji odgovara mesečnoj kapitalizaciji i mesečnoj relativnoj kamatnoj stopi je 1,009166667, zatim, na dvanaesti stepen, 1,009166667 $7^{12}=1,1157188362$, što je za oko 0,52\% veće od godišnjeg kamatnog faktora. Na drugoj strani pri kamatnoj stopi od $110 \%$ razlika između godišnjeg kamatnog faktora 2,10 i mesečnog 2,86471 (mesečni kamatni faktor na dvanaesti stepen 1,091666667 ${ }^{12}$ ) je mnogo veća. Relativna kamatna stopa sa mesečnim pripisom kamata za 36,41\% donosi veću vrednost glavnice nego godišnjim, pri čemu se može zaključiti da češća kapitalizacija donosi veću konačnu vrednost. Stoga, pri velikim godišnjim kamatnim stopama korišćenje relativne kamatne stope nema smisla.

Konformnom kamatnom stopom očigledno se pokušava eliminisati glavni nedostatak relativne kamatne stope. Realizacija ekonomskog načela podrazumeva da data početna vrednost glavnice $\mathrm{C}_{0}$ uz primenu nove kamatne stope i češće kapitalizacije donosi istu konačnu vrednost kao godišnja kamatna stopa i godišnja kapitalizacija. To znači, da je za kreditora nepovoljnije da mu se kredit vrati u jednom iznosu tačno po isteku godine dana, nezavisno od toga kako je česta bila kapitalizacija. Konformnu kamatnu stopu koja odgovara godišnjem periodu kapitalizacije M najlakše možemo iznaći tako što ćemo izračunati kamatni konformni faktor a zatim na osnovu njega kamatnu stopu. Dakle, imamo dekurzivni obračun, godišnju kamatnu stopu $p \%$ i kapitalizaciju kamata $\mathrm{M}$ puta godišnje. Traženu konformnu kamatnu stopu možemo označiti sa $p_{\mathrm{kM}}$. Konačna vrednost glavnice $\mathrm{C}_{0}$ je pri godišnjoj kapitalizaciji jednaka $C_{0}(1+p / 100)$. Za M-puta kapitalizacije u toku godine, koristeći osnovni obrazac složenog kamatnog računa izračunavamo odgovarajuću konačnu vrednost tako što ćemo $\mathrm{C}_{0}$ pomnožiti sa M-tom potencijom kamatnog faktora za novi period kapitalizacije. Na osnovu zahteva da konačne vrednosti budu jednake imamo sledeću jednačinu:

$$
1+\frac{\mathrm{p}}{100}=\left(1+\frac{\mathrm{p}_{\mathrm{kM}}}{100}\right)^{\mathrm{M}}
$$


We shall use the general format for compound interest calculation:

$\mathrm{C}_{\mathrm{n}}=\mathrm{C}_{0} \mathrm{r}^{\mathrm{n}}=5,000,000 \times 1.06^{5}$

$\mathrm{C}_{\mathrm{n}}=5,000,000 \times 1.33822558=6,691,127.89$

$\mathrm{C}_{\mathrm{n}}=\mathrm{C}_{0} \mathrm{r}^{\mathrm{n}}=5,000,000 \times 1.09^{5}$

$C_{n}=5,000,000 \times 1.538624=7,693,119.77$

In the first case, discounting factor is 1.06 and in the second case 1.09; fifth potentials of these two factors are: $1,06^{5}=1,33822558$ and $1,09^{5}=1,538624$, which means that we have: a) final principal of $6,691,127.89$ dinars, interest $1,1691,127.89$ dinars. In the second case b) the final principal is 7,693,119.77 dinars, interest is 2,693,119.77 dinars. Interest quotient is 1.59.

De facto, when increasing interest rates for $50 \%$ we obtain an increase of the interest higher than $59 \%$. This is certainly in all respects a significant difference in comparison with the simple interest calculation where the interests are directly proportional to the interest rate. Therefore the following rule applies: As soon as the interest is calculated, by applying compound interest calculation, at least for two periods, the percentage of interest increase exceeds the percentage of increase of the interest rate.
The basic format of the compound interest calculation shows that the principal is increasing as a geometric series, which corresponds to a continuous exponential growth. It is important to note that in this case it is not a question only of the "ascending step-ladder", but also of an increase in the level of individual step-ladder steps, as the basis for interest calculation. The amount of interest is increasing from year to year. On the basis of the basic format of the compound interest account we can calculate any one of the unknown values, if the remaining three are known:

a. Original principal we can find by using the primary knowledge: $C_{n}=C_{0} r^{n} \Rightarrow C_{0}=\frac{C_{n}}{r^{n}}$

Let us look at the following example:

How much money do we have to deposit at the bank in order to have, with the interest rate of $7 \%$ and the annual capitalisation after 12 years, the amount of 1,000,000.00 dinars?

$$
\mathrm{C}_{0}=\frac{\mathrm{C}_{\mathrm{n}}}{\mathrm{r}^{\mathrm{n}}}=\frac{1.000 .000}{1,07^{12}}=444.011,96
$$

b. We can calculate interest rates by previously calculating the unknown discounting factor, and on its basis in accordance with the definition of the discounting factor, we can easily obtain the interest rate by reducing factor $r$ for 1 , and move the decimal point for two places to the right.
Figure 3. Compound interest calculation - graphical representation

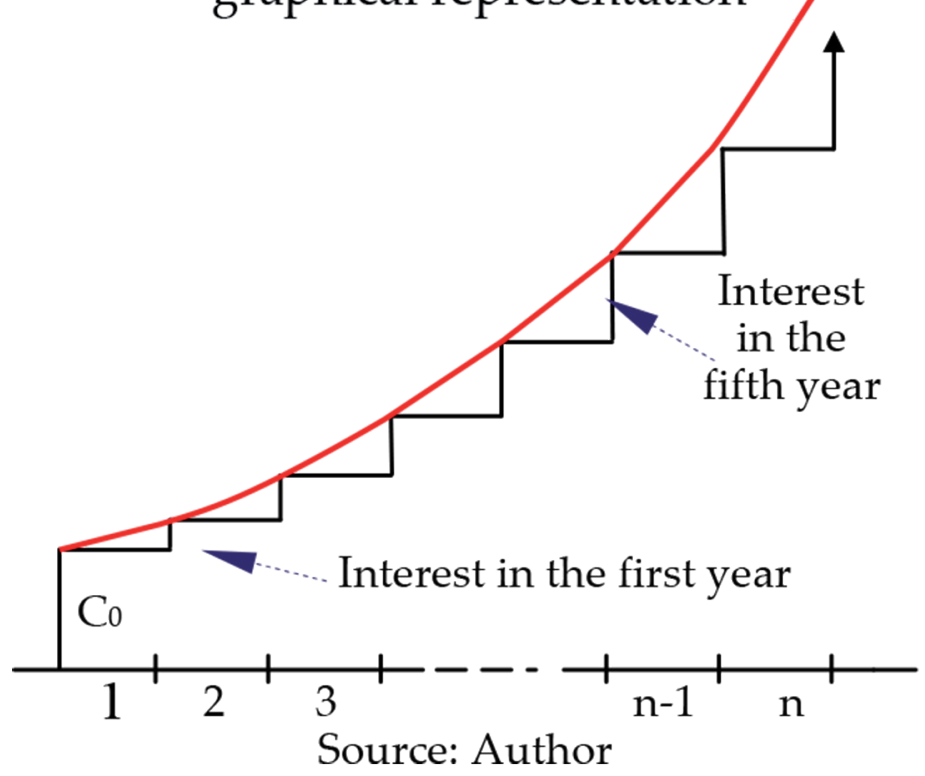

$C_{n}=C_{0} r^{n} \Rightarrow r^{n}=\frac{C_{n}}{C_{0}} \Rightarrow r=\sqrt[n]{\frac{C_{n}}{C_{0}}}$

Example: The Company has deposited at the bank 31,000.00 dinars, and after five years received notification that the amount of 14,549.93 dinars was accrued as interest. At what interest rate were the interests calculated if the bank used compound interest account and annual capitalisation?

The easiest way to calculate the amount of the interest rate is to calculate, on the basis of the original principal and interest, the final principal by means of the following format:

$\mathrm{r}=\sqrt[n]{\frac{\mathrm{C}_{\mathrm{n}}}{\mathrm{C}_{0}}}=\sqrt[5]{\frac{31.000,00+14.549,93}{31.000,00}}$ 
iz koje možemo da izvedemo obrazac za konformnu kamatnu stopu $\mathrm{p}_{\mathrm{kM}}$ :

$$
\mathrm{p}_{\mathrm{kM}}=100\left(\sqrt[M]{1+\frac{\mathrm{p}}{100}}-1\right)
$$

Očigledno je da se pri upotrebi ovog obrasca srećemo sa konkretnim vrednostima za M (kvadratni koren za polugodišnje kapitalizacije, četvrti za kvartalne, dvanaesti za mesečne a 365-ti odnosno, 366-ti za najčešće dnevne kapitalizacije).

Primer: Izračunajmo pripadajuću konformnu kamatnu stopu za polugodišnju i kvartalnu kapitalizaciju ako je kamatna stopa $11 \%$, p.a. i uporedimo ih sa odgovarajućim relativnim kamatnim stopama iz prethodnog primera.

Konformni kamatni faktor $r$ dobija se iz nominalnog jednostavnim računanjem m-tog korena. Za kamatnu stopu 11\% godišnji kamatni faktor $r$ iznosi 1,11, dakle odgovarajući konformni kamatni faktor (zaokružen na osam decimalnih mesta):

$$
\begin{aligned}
& \mathrm{r}_{\mathrm{S}}=\sqrt{1+\frac{11}{100}}=1,053565375 \\
& r_{q}=\sqrt[4]{1+\frac{11}{100}}=1,026433327
\end{aligned}
$$

Jasno je da su pripadajuće kamatne stope $5,36 \%$ p.s. i $2,64 \%$ p.q. manje od relativne polugodišnje kamatne stope $\mathrm{p} / 2=5,5 \%$; $\mathrm{i}$ relativne kvartalne kamatne stope $\mathrm{p} / 4=2,75 \%$.

Primetimo još jednom razliku između konformne i relativne kamatne stope. U slučaju kada je $\mathrm{M}>1$ (češći pripis kamata) relativna kamatna stopa je veća od konformne i samim tim daje veće kamate i veću konačnu vrednost. Primer jasno pokazuje (čak i za naše pojmove) da razlike između relativne i konformne kamatne stopenisu zanemarljive čakni kod nižih kamatnih stopa. Istina je, da se padanjem kamatnih stopa te razlike smajuju, međutim, činjenica je da dužnik koji je posudio $10.000 .000,00$ dinara na tri meseca po godišnjoj stopi od $11 \%$ primenom konformne kamatne stope treba da plati $264.333,27$ dinara kamata, ali primenom relativne kamatne stope celih 275.000,00 dinara. Generalno, imamo dve nesporne činjenice:

1. kada su kamatne stope visoke upotreba relativne kamatne stope potpuno je besmislena, nekorektna i sa aspekta dužnika predstavlja "zelenaštvo";

2. kada su kamatne stope niže (veličine svega nekoliko procenata) upotreba relativne kamatne stope je primerena, jer je vrlo jednostavno približna konformnoj kamatnoj stopi, stoga ne začuđuje da je u zapadnim finansijskim sistemima "proporcionalni metod" uprkos kritikama EU još uvek dominantno pravilo za obračun kamata.

Kada znamo da izračunamo konformni kamatni faktor za jedan period kapitalizacije, nastavak računanja se jednostavno svodi samo na primenu osnovnog obrasca složenog kamatnog računa $\mathrm{C}_{\mathrm{n}}=\mathrm{C}_{0} \mathrm{r}^{\mathrm{n}}$, koji je potpuno univerzalan, $\mathrm{s}$ tim da treba voditi računa da se vrednost kamatnog faktora prilagodi stvarnom periodu kapitalizacije i da imamo za eksponent broj takvih perioda. One koji su možda zaboravili tajanstvene sekundarne pristupe u izračunavanju korena, da podsetimo da koren možemo da napišemo $u$ formi stepena gde je eksponent razlomak.

Dakle, u opštem slučaju važi ekvivalentnost zapisa: $\sqrt[m]{x^{n}}=(\sqrt[m]{x})^{n}=x^{n / m}$. Pri tome, ne treba zaboraviti da stepenovanje ima prednost $\mathrm{u}$ odnosu na deljenje, pa količnik u eksponentu moramo staviti u zagradu. Pomoću kalkulatora lako možemo da izračunamo odgovarajuće korene. Za obračun kamata za tipične poslove $\mathrm{u}$ okviru jedne godine $\mathrm{u}$ principu imamo najmanje tri načina: (1) prosti kamatni račun; (2) složeni kamatni račun - konformni obračun i (3) složeni kamatni račun - relativni obračun. Pogledajmo na konkretnom primeru koliki su iznosi kamate primenom sva tri načina, uz ostale nepromenjene varijable (glavnica, godišnja kamatna stopa, period kapitalizacije). Pošto je vreme izraženo u danima, za obe verzije složenog kamatnog računa koristićemo dnevnu kapitalizaciju.

Tri banke obračunavaju kamate na depozit $10 \%$ godišnje, pri čemu prva upotrebljava prosti kamatni račun, druga konformnu verziju složenog kamatnog računa sa dnevnom kapitalizacijom i treća složeni kamatni račun i relativnu kamatnu stopu. Koja je konačna vrednost uloga kod sve tri banke nakon 185 dana, ako je u svaku uloženo po milion i pet stotina hiljada dinara?

Kod prve banke koja primenjuje prosti kamatni račun konačna vrednost je: 
$r=\sqrt[5]{1,46935258}=1,0800036 \ldots$

This shows, after rounding up, that the annual interest rate is exactly $8 \%$.

c. Slightly more exacting is calculation of time.

Let us see what it looks like on a concrete example. How much time is it necessary for the principal to double in size, if the annual interest rate is $8 \%$, capitalisation is annual, and the decursive calculation is applied? Doubling in size means that $\mathrm{C}_{n}=2 \mathrm{C}_{0^{\prime}}$ interest factor is 1.08 , so that we have the following:

$\mathrm{C}_{\mathrm{n}}=\mathrm{C}_{0} \mathrm{r}^{\mathrm{n}} \Rightarrow$

$\log C_{n}=\log C_{0}+n \log r \Rightarrow n=\frac{\log C_{n}-\log C_{0}}{\log r}$ $\mathrm{n}=\frac{\log 2 \mathrm{C}_{0}-\log \mathrm{C}_{0}}{\log \mathrm{r}}=\frac{\log 2}{\log 1,08}=9,006468342$

On the basis of the result obtained we can conclude that at the interest rate of $8 \%$ the principal will double in size in nine years.

\section{Relative and conform interest rate}

During the period of high interest rates the rule that applied in practice was shortening of the period of annual capitalisation to underannual term, so that accounting debt balance could be as close as possible to the real status. In this respect, problem emerges with what interest rate to ascribe interest to such (shorter or longer) time periods. There are two options that bring us to the notion of relative and conform interest rate. For the given period of capitalisation we can obtain relative interest rate by dividing the annual interest rate with number $M$, which speaks of how many times is the period of capitalisation shorter than one year. Hence the semi-annual interest rate is one half of the annual interest rate, quarterly is one quarter, monthly one twelfth, and daily $1 / 365$ or $1 / 366$ for the leap year. This procedure is obviously very simple but not completely correct. By consistent application of the relative interest rate with under-annual capitalisation we obtain higher final values of principal than the values that we would obtain when applying annual interest rate $\mathrm{p}$ together with annual capitalisation. For purpose of easier understanding of this problem, let us analyze the following example.

Let us check whether the final value obtained by applying nominal and relative interest rates will be the same or not. What are the differences between the principal value of 100 monetary units upon expiry of one year with annual, semiannual, quarterly and monthly capitalisation by applying relative interest rate where the annual interest rate is: a) $\mathrm{p}=11 \%$ and b) $\mathrm{p}=110 \%$ ?

\begin{tabular}{|l|l|c|l|l|}
\hline \multirow{2}{*}{$\begin{array}{c}\text { Interest } \\
\text { rate }\end{array}$} & \multicolumn{4}{|c|}{ Capitalisation } \\
\cline { 2 - 5 } & annual & $\begin{array}{c}\text { semi- } \\
\text { annual }\end{array}$ & quarterly & monthly \\
\hline $11 \%$ p.a & 111.00 & 111.30 & 111.46 & 111.57 \\
\hline $110 \%$ p.a. & 210.00 & 240.25 & 264.27 & 286.47 \\
\hline
\end{tabular}

The differences are obviously growing with the growth of the interest rate and more frequent capitalisation. For the interest rate $\mathrm{p}=11 \%$ and the annual capitalisation the interest factor is $1+11 / 100=1.11$. The interest factor which corresponds to the monthly capitalisation and monthly relative interest rate is 1.009166667 , then on the twelfth degree, $1.009166667^{12}=$ 1.1157188362 , which is for some $0.52 \%$ higher than the annual interest factor. On the other side, in case of the interest rate of $110 \%$ the difference between the annual interests factor 2.10 and monthly 2.86471 (monthly interest factor on the twelfth degree $1.091666667^{12}$ ) is much higher. Relative interest rate with monthly interest accrual for $36.41 \%$ brings higher value to the principal than with the annual, where it may be concluded that more frequent capitalisation brings about high final value. Hence, in case of high annual interest rates the use of relative interest rate makes no sense.

Conform interest rate obviously serves as an attempt to eliminate the main shortcomings of the relative interest rate. Implementation of the economic principle implies that the original value of principal $\mathrm{C}_{0^{\prime}}$ with the application of the new interest rate and more frequent capitalisation, brings about the same final value as the annual interest rate and annual capitalisation. This means that it is less opportune for the creditor for his loan to be 


$$
\begin{aligned}
\mathrm{C}_{185} & =\mathrm{C}_{0}+\frac{\mathrm{Cpd}}{36500} ; \\
\mathrm{C}_{185} & =1.500 .000+\frac{1.500 .000 \times 10 \times 185}{36500}=1.576 .027,40
\end{aligned}
$$

pod pretpostavkom primene $(K, 365)$ načina brojanja dana. U drugoj banci u tom trenutku se akumuliralo:

$$
\mathrm{C}_{185}=\mathrm{C}_{0} \mathrm{r}^{185}=1.500 .000\left[\sqrt[365]{1+\frac{10}{100}}\right]^{185}=1.574 .240,62
$$

Treća banka je maksimizirala glavnicu, odnosno:

$$
\mathrm{C}_{185}=\mathrm{C}_{0} \mathrm{r}^{185}=1.500 .000\left[1+\frac{\frac{10}{365}}{100}\right]^{185}=1.577 .976,13
$$

Da je rezultat koji smo dobili upotrebom relativne kamatne stope viši od onoga koji odgovara konformnom postupku, nikoga ne iznenađuje. Ali, za ispodgodišnji period konformne kamate su manje od odgovarajućih kamata obračunatih primenom prostog kamatnog računa. Detaljnim poređenjem uočavamo da:

- na kraju prve godine dobijamo jednake kamate primenom prostog kamatnog računa i konformnog složenog obračuna;

- što je nominalna kamatna stopa veća, veća je i razlika koja se javlja upotrebom relativne kamatne stope;

- iznos kamate dobijen primenom konformnog obračuna je tokom godine konstantno manji od iznosa dobijenog prostim kamatnim računom;

- najveća razlika između navedenih iznosa je polovinom godine (na sredini), njena veličina je rastuća funkcija inicijalne godišnje kamatne stope;

- u uslovima niskih realnih kamatnih stopa povećava se motiv za zaduživanje i smanjuje motiv za kreditiranje.

\section{Stvarna cena kredita}

Ako posmatramo određenu kreditnu transakciju kao finansijski tok, možemo da uočimo da se $u$ njemu pored pozajmljenog iznosa (koji dospeva odjednom ili u više rata) i periodične otplate obično pojavljuju i određeni troškovi - naknade i provizije za korisnika kredita koji nastaju po osnovu ugovorene kamatne stope. S tim u vezi se može postaviti hipoteza da na povećanje kreditorove profitabilnosti takođe, utiču i nekamatni prihodi kod takvih transakcija. Za sintetički parametar, kojim izražavamo cenu novca, uobičajeno se uzima efektivna kamatna stopa (EKS). EKS omogućava da uporedimo troškove ili povrate među proizvodima koji imaju različitu strukturu naknada i druge uslove. Zakonom o zaštiti korisnika finansijskih usluga propisano je da su banke dužne da efektivnu kamatnu stopu obračunavaju na jedinstven propisan način radi poređenja istovetnih ponuda različitih davalaca finansijskih usluga. Značaj ovog parametra je vrlo jasan: bar načelno daje mogućnost da unapred procenimo koliko će nas zaista koštati novac, pri čemu se izbegava rizik procene samo na osnovu objavljene kreditorove kamatne stope koja je inače značajna, ali ne i jedini element cene pozajmljenog novca. Korišćenjem efektivne kamatne stope odnosi na kreditnom tržištu postaju znatno transparentniji. U pojedinim evropskim zemljama je relativno rano propisano korišćenje EKS kao osnove za poređenje konkurentskih kreditnih ponuda, posebno kod potrošačkih kredita, kod kojih su inače (zbog neprofesionalnih kupaca) mogućnosti za prevaru, objektivno govoreći, znatno veće nego kod kredita privredi. Stoga, kod najobičnije primene principa ekvivalencije glavnice: na jednoj strani svi prilivi, na drugoj svi odlivi, EKS koriguje oba dela finansijskog toka tako da sadašnje vrednosti postanu jednake. Parametar EKS je jednak onoj godišnjoj kamatnoj stopi koja se dobije rešenjem sledeće jednačine:

$$
\sum_{j=1}^{m} \frac{a_{j}}{(1+i)^{t_{j}}}=\sum_{k=1}^{n} \frac{b_{k}}{(1+i)^{t_{k}}}
$$

Iako je svakom ekonomisti ovaj izraz $u$ potpunosti jasan ipak, radi kompletnosti zapisa detaljnije ćemo predstaviti navedene elemente, čiji se značaj ponekad pogrešno tumači i dodati još neka upozorenja koja ni profesionalcima nisu sivišna. Simboli znače: M- ukupan broj primljenih iznosa; $a_{j}-$ pojedinačno primljeni iznosi; $t_{j}$ - trajanje godišnjeg ili ispodgodišnjeg intervala od dospeća prvog primljenog iznosa do valute j-tog primljenog iznosa; n- ukupan broj plaćenih iznosa; $b_{k}$ - pojedinačno plaćeni iznosi; $t_{\mathrm{k}}$ - trajanje godišnjeg ili ispodgodišnjeg intervala od momenta dospeća prvog primljenog 
repaid in one single amount precisely upon expiry of the period of one year, irrespective of how frequent was the capitalisation. Conform interest rate which corresponds to the annual period of capitalisation M may be most easily found by calculating the interest conform factor, and then on its basis the interest rate. Hence, we have decursive calculation, annual interest rate $p \%$ and interest capitalisation $\mathrm{M}$ times per year. The required conform interest rate may be designated with pkM. The final value of principal $\mathrm{C}_{0}$, with the annual capitalisation is equal to $C_{0}(1+p / 100)$. For $M$-times capitalisation during one year, using the basic format of compound interest account, we calculate the corresponding final value by multiplying $\mathrm{C}_{0}$ with Mth potential of the interest factor for the new period of capitalisation. On the basis of the requirement for the final values to be equal, we have the following equation:

$$
1+\frac{\mathrm{p}}{100}=\left(1+\frac{\mathrm{p}_{\mathrm{kM}}}{100}\right)^{\mathrm{M}}
$$

from which we can derive the format for the conform interest rate $\mathrm{P}_{\mathrm{kM}}$ :

$$
\mathrm{p}_{\mathrm{kM}}=100\left(\sqrt[M]{1+\frac{\mathrm{p}}{100}}-1\right)
$$

Obviously when this format is applied we encounter concrete values for $M$ (square root of semi-annual capitalisation, fourth for the quarterly, twelfth for monthly, and 365th i.e. 366th for the most frequent daily capitalisations).

Example: Let us calculate now the conform interest rate for the semi-annual and quarterly capitalisation if the interest rate is $11 \%$, p.a and compare them with corresponding relative interest rates from the previous example.

Conform interest factor $r$ is obtained from the nominal one by a simple calculation of the mth root. For the interest rate of $11 \%$ the annual interest factor $r$ amounts to 1.11, hence the corresponding conform interest factor (rounded up to eight decimal places):

$$
\begin{aligned}
& \mathrm{r}_{\mathrm{S}}=\sqrt{1+\frac{11}{100}}=1,053565375 \\
& r_{q}=\sqrt[4]{1+\frac{11}{100}}=1,026433327
\end{aligned}
$$

Obviously, the respective interest rates 5.36\% p.s. and $2.64 \%$ p.q. are lower than the relative semi-annual interest rate $\mathrm{p} / 2=5.5 \%$; and the relative quarterly interest rate $\mathrm{p} / 4=2.75 \%$.

We shall notice here once again the difference between conform and the relative interest rate. In case when $M>1$ (more frequent interest accrual) relative interest rate is higher than the conform one and thus is yielding higher interests and higher final value. Example clearly shows (even in our own perception) that differences between relative and conform interest rates are not negligible even in case of lower interest rates. It is true that with the fall of interest rates these differences are decreasing, however, the fact that the debtor who had borrowed 10,000,000.00 dinars with a three months maturity at an annual rate of $11 \%$, with the application of the conform interest rate should pay $264,333.27$ dinars of interest, but with the application of the relative interest rate he must pay as much as $275,000.00$ dinars. Generally speaking, we have two undisputable facts:

1. When interest rates are high, application of the relative interest rate is a complete nonsense, it is not correct and from the aspect of the debtor it is "loan sharking";

2. When interest rates are lower (in the value of only several percentages) the application of the relative interest rate is appropriate, because it is very simply close to the conform interest rate, and it is not surprising that in the western financial systems the "proportional method", in spite of EU criticism, is still a predominant rule for interest rate calculation.

Once we have mastered computation of the conform interest factor for one period of capitalisation, continued calculation is simply brought down to the application of the basic format of the compounded interest account $\mathrm{C}_{\mathrm{n}}=\mathrm{C}_{0} \mathrm{r}^{\mathrm{n}}$, which is completely universal, but what must be taken into account is that the value of the interest factor must be adjusted to the real period of capitalisation and that we have for the exponent the number of such periods. Let us remind those who have perhaps forgotten the mysterious secondary approaches to the calculation of roots that we can write down the root in the form of the degree where the exponent is the fraction.

Therefore, what generally prevails is the 
iznosa do valute k-tog plaćenog iznosa. Kao što možemo da vidimo, dolazi do finansijskih tokova koji se odvijaju potpuno proizvoljno. Vremenski intervali koji se pojavljuju u imeniocu sa obe strane jednačine mogu biti bilo koji, ali svaki od njih se meri od dospeća prvog iznosa koji dužnik prima po osnovu odobrenog kredita. Traženu kamatnu stopu $i$ možemo izračunati na tri načina: algebarskim rešavanjem jednačine, uzastopnim aproksimacijama, ili pomoću računara. Ipak, preporuka je da se radi preciznosti i brzine računanja koristi treća opcija. Radi detaljnijeg prikaza uticaja administrativnih fiksnih troškova na EKS sumiraćrmo dva pojednostavljena primera.

Primer 1. Po kojoj efektivnoj kamatnoj stopi je posuđen novac ako smo 01.01.2010. godine uzeli zajam u iznosu od 1.100,00 \$ i vratili $1.350,00$ \$ 30.06.2011?

$\mathrm{Na}$ levoj strani prethodne jednačine je iznos primljenog zajma, (od kojeg nije oduzeta kamata), jer je njegova valuta startni datum za računanje kamatnog perioda. Dužina vremenskog intervala vraćanja zajma do 30.06.2011. prema našem brojanju dana (uzimamo u obzir prvi dan a poslednji ne) iznosi 545 dana: $(365+31+28+31+30+31+29=545)$.

$$
1.100,00=\frac{1.350,00}{(1+i)^{\frac{545}{365}}} \Rightarrow 1+\mathrm{i}=1,1470069
$$

$\mathrm{EKS}=14,70 \%$

Primer 2. Analizirajmo za koliko će se promeniti rezultat iz prethodnog primera ako uzmeno u obzir da je dužnik morao u skladu sa ugovorom o kreditu platiti 56 \$ na ime manipulativnih troškova?

Ova promena znači da je dužnik umesto 1.100 \$ primio samo $1.044 \$$, što primenom istog postupka daje sledeću EKS:

$$
\begin{aligned}
& 1.044,00=\frac{1.350,00}{(1+i)^{\frac{545}{365}}} \Rightarrow 1+\mathrm{i}=1,1879 \\
& \Rightarrow \mathrm{EKS}=18,80 \%
\end{aligned}
$$

Poređenjem dobijenih rezultata uočavamo da je osnovni efekat administrativnih fiksnih troškova jasno vidljiv - kredit sada košta kao da je odobren po godišnjoj kamatnoj stopi od 18,80\% i bez dodatnih troškova. U tom kontekstu treba istaći i to da se EKS ne može koristiti za direktno poređenje kreditnih poslova ako se razlikuju ostali kreditni uslovi.

\section{Kratkoročne transakcije}

Za ilustraciju razlika u performansama u nastavku ćemo oblikovati nekoliko pojednostavljenih primera.

Za početak pretpostavimo da dve investicije koje obezbeđuju godišnji prinos od $11 \%$, dospevaju za 185 dana. Za prvu se koristi prosti a za drugu konformni obračun kamate. Kolika je razlika u prinosima i koliki bi trebao da bude godišnji prinos druge investicije da bi u datom trenutku dala isti prinos kao prva?

Prinos koji ostvaruje prva investicija za 185 dana (neprestupna godina) je jednak:

$$
\begin{aligned}
& \frac{C p d}{36500}=\frac{C \times 11 \times 185}{36500}=0,055753 \ldots . . C \Rightarrow(5,57 \%) C \\
& \text { A druga: } \\
& C\left(\left(1+\frac{p}{100}\right)^{d / 365}-1\right)=C\left(1,11^{185 / 365}-1\right)=0,05432 \ldots \\
& C \Rightarrow(5,43 \%) C .
\end{aligned}
$$

Razlika između ova dva rezultata je očigledna. Oni koji se bolje razumeju u apsolutne i relativne greške, reći će da je razlika značajnija ukoliko je glavnica $C$ veća. Generalno, da bi druga investicija postigla isti prinos, njen godišnji prinos bi trebao biti takav da vredi:

$$
\frac{C p_{N} d}{36500}=C\left(\left(1+\frac{p_{K}}{100}\right)^{d / 365}-1\right)
$$

ili

$$
\begin{gathered}
\mathrm{p}_{\mathrm{K}}=100\left(\left(1+\frac{\mathrm{p}_{\mathrm{N}} \mathrm{d}}{36500}\right)^{365 / \mathrm{d}}-1\right) \\
\mathrm{p}_{\mathrm{K}}=100\left(\left(1+\frac{11 \times 185}{36500}\right)^{365 / 185}-1\right)=11,30 \%
\end{gathered}
$$

Na osnovu numeričke ilustracije i dobro poznate činjenice da pri datoj kamatnoj stopi 
equivalency of writ: $\sqrt[m]{x^{n}}=(\sqrt[m]{x})^{n}=x^{n / m}$. It should not be forgotten here that rising to a power has the advantage in respect to division, so that we must place the quotient in the exponent between brackets. By means of calculator we can easily compute the corresponding roots. For the computation of the interest rates for typical deals within the scope of one year in principle we have at least three manners at our disposal: (1) the simple interest calculation; (2) the compounded interest calculation - conformed calculation, and (3) the compounded interest calculation - relative calculation. Let us have a look at a concrete example and find out what are the amounts of interest by the application of all of these three methods, together with the other unchangeable variables (principal, annual interest rate, period of capitalisation). As the time is expressed in days for both versions of the compound interest account we will apply daily capitalisation.

There are three banks that are calculating interest rate on deposits of $10 \%$ annually, where the first one is using the simple interest calculation, the second one conform version of the compounded interest calculation with daily capitalisation, and the third one is applying the compounded interest calculation and the relative interest rate. What is the final value of deposit in all of the three banks after 185 days, if in each one of the banks deposit was made of one million five hundred thousand dinars?

In case of the first bank which is applying the simple interest calculation, the final value is:

$\mathrm{C}_{185}=\mathrm{C}_{0}+\frac{\mathrm{Cpd}}{36500}$

under the assumption that the $(K, 365)$ was applied as the manner of counting days.

In the second bank, at that moment, the accumulation was the following:

$\mathrm{C}_{185}=\mathrm{C}_{0} \mathrm{r}^{185}=1.500 .000\left[\sqrt[365]{1+\frac{10}{100}}\right]^{185}=1.574 .240,62$

The third bank had maximized the principal:

$$
\mathrm{C}_{185}=\mathrm{C}_{0} \mathrm{r}^{185}=1.500 .000\left[1+\frac{\frac{10}{365}}{100}\right]^{185}=1.577 .976,13
$$

It comes as no surprise to anyone that the result which we have obtained by applying the relative interest rates is higher than the one which corresponds to the conform procedure. Yet for the under-annual period, conform interests are lower than the corresponding interests calculated by using the simple interest account. Detailed comparison shows us the following:

- By the end of the first year we obtain equal interests when applying the simple interest calculation and the conform compounded calculation;

- The higher the nominal interest rate, the higher the difference which appears when using the relative interest rate;

- The amount of interest obtained when using the conform calculation is during the year constantly lower than the amount obtained by the simple interest calculation;

- The highest difference between the said amounts appears in the middle of the year (in the mean), and its value is the growing function of the initial annual interest rate;

- In the situation of low real interest rates motivation is on the rise for borrowing and motivation falls for crediting.

\section{Real price of credit}

If we are to assess a certain credit transaction as a financial flow we can notice that within this flow, in addition to the amount borrowed (which matures either in one term or in several repayment instalments) and the periodical repayment, what usually appear are also certain costs - fees and commissions to be charged on the credit beneficiary, which arise on the basis of the contracted interest rate. In with respect a hypothesis may be made that on the increase of the creditor's profitability what also has an impact are the non-interest revenues in such transactions. For the synthetic parameter which serves to express the price of money, what is usually used is the effective interest rate (EIR - EKS). EIR allows us to compare costs or returns among products which have a different structure of fees and other conditions. The Law on Protection of Users of Financial Services prescribes that the banks must calculate the effective interest rate in a single prescribed manner for purpose of comparison between identical offers of different providers of financial 
proste kamate u okviru jedne godine rastu brže nego konformne, uočavamo da obračun kamata za 185 dana po stopi od $11 \%$ pokazuje da je prinos dobijen po prostom kamatnom računu ekvivalentan godišnjem konformnom rastu glavnice koju daje godišnja kamatna stopa $11,30 \%$. Istovremeno, rezultat nije ovisan samo o određenoj kamatnoj stopi, nego i o trajanju posla. Pri datoj kamatnoj stopi razlike su najveće kod srednjoročnih $\mathrm{HoV}$ (npr. šestomesečne). Na godišnjem nivou, razlike svakako nema, jer je konformna kamatna stopa određena tako da godišnji prinos bude jednak onom koji bi dobili primenom prostog kamatnog računa. S obzirom da je konformni obračun kamate poslednjih godina bio dominantan metod kod kratkoročnih depozita, posebno kada govorimo o bankarskom sektoru, primena drugih načina zahteva da se rezultati konvertuju u ekvivalentnu konformnu kamatnu stopu. Ovo posebno važi ako se odstupanju od konformog obračuna pridružuju sledeći prateći elementi:

a) posrednoizražavanje prinosa s diskontovanom vrednosti investicije na početku transakcije; ili kursom hartije od vrednosti kao procenta njene konačne vrednosti i

b) različiti načini brojanja dana, na primer, upotreba 360 dana kao standardne dužine godine. ${ }^{1}$

U kontekstu navedenog analizirajmo sledeći primer.

Pretpostavimo da će dužnik za d dana vratiti glavnicu C i pripadajuće dekurzivne kamate obračunate po konformnom metodu uz godišnju kamatnu stopu $p_{K}(\%)$. Koliko bi iznosila ekvivalentna godišnja kamatna stopa $p_{N}$ ako bi primenili prosti kamatni račun?

Radi se o obrnutoj funkciji čije rešenje je naročito značajno za one koji su već vezali sredstva uz konformnu kamatnu stopu, ali su međutim, inspirisani drugim opcijama. $p_{N}$ se dobija rešavanjem sledeće jednačine nakon čega se popunjava tabela.

$\mathrm{p}_{\mathrm{N}}=\frac{36500}{\mathrm{~d}}\left(\left(1+\frac{\mathrm{p}_{\mathrm{K}}}{100}\right)^{\mathrm{d} / 365}-1\right)$
Tabela 1. Pregled preračunatih dekurzivnih prostih kamatnih stopa u ekvivalentne dekurzivne konformne kamatne stope

\begin{tabular}{|l|c|c|c|c|c|c|}
\hline \multirow{2}{*}{ Dani } & \multicolumn{5}{|c|}{ Kamatna stopa } \\
\cline { 2 - 7 } & $5 \%$ & $7 \%$ & $9 \%$ & $10 \%$ & $12 \%$ & $15 \%$ \\
\hline 5 & $4,88 \%$ & $6,77 \%$ & $8,62 \%$ & $9,54 \%$ & $11,34 \%$ & $13,99 \%$ \\
\hline 10 & $4,88 \%$ & $6,77 \%$ & $8,63 \%$ & $9,54 \%$ & $11,35 \%$ & $14,00 \%$ \\
\hline 15 & $4,88 \%$ & $6,78 \%$ & $8,63 \%$ & $9,55 \%$ & $11,36 \%$ & $14,02 \%$ \\
\hline 20 & $4,89 \%$ & $6,78 \%$ & $8,64 \%$ & $9,56 \%$ & $11,37 \%$ & $14,03 \%$ \\
\hline 25 & $4,89 \%$ & $6,78 \%$ & $8,64 \%$ & $9,56 \%$ & $11,38 \%$ & $14,04 \%$ \\
\hline 30 & $4,89 \%$ & $6,78 \%$ & $8,65 \%$ & $9,57 \%$ & $11,39 \%$ & $14,06 \%$ \\
\hline 60 & $4,90 \%$ & $6,80 \%$ & $8,68 \%$ & $9,61 \%$ & $11,44 \%$ & $14,14 \%$ \\
\hline 90 & $4,91 \%$ & $6,82 \%$ & $8,71 \%$ & $9,64 \%$ & $11,49 \%$ & $14,22 \%$ \\
\hline 120 & $4,92 \%$ & $6,84 \%$ & $8,74 \%$ & $9,68 \%$ & $11,55 \%$ & $14,30 \%$ \\
\hline 180 & $4,94 \%$ & $6,88 \%$ & $8,80 \%$ & $9,76 \%$ & $11,66 \%$ & $14,47 \%$ \\
\hline
\end{tabular}

U mnogim slučajevima, imamo mogućnost obavljanja kratkoročnih poslova na način da dužnik primi diskontovanu vrednost nekog "okruglog" konačnog ugovorenog iznosa. Diskont može biti pokrenut kako na anticipativan tako i na dekurzivan način. Prvi je karakterističan za klasične menice, gde se menični diskont oduzima od nominalne vrednosti glavnice. Sličan pristup srećemo $\mathrm{u}$ proceni raznih trezorskih i blagajničkih zapisa, sličnih kratkoročnih hartija od vrednosti kao i kod drugih klasičnih kratkoročnih kreditnih poslova. Radi objašnjenja razlika u obračunima oblikovan je sledeći primer.

Preduzeće je dobilo ponudu od banke za kredit za likvidnost na $d$ dana sa anticipativnim prostim kamatama i godišnjom kamatnom stopom $\mathrm{p}_{\mathrm{AN}}$. Kolika treba da bude kamatna stopa $\mathrm{p}_{\mathrm{K}}$ druge banke koja koristi konformni dekurzivni obračun sa dnevnom kapitalizacijom da bi uslovi bili ekvivalentni?

Pre svega, ne smemo zaboraviti da kod anticipativnog obračuna osnovicu za obračun kamate čini konačna vrednost glavnice. Dužnik zapravo dobija (na početku) umanjenu glavnicu, što znači da smo u potrazi za konformnom godišnjom kamatnom stopom $p_{K}$ koja će na anticipativan način umanjenu glavnicu $C$ ponovo vratiti na njenu početnu vrednost. To

1 S tim u vezi treba napomenuti da Evropa sistematski podstiče primenu preciznog računanja vremena - Exact/Exact ili Atual/Actual, ili pak primenu japanskog načina - Actual/365. 
services. The significance of this parameter is very clear: at least in principle, an opportunity is given to us to assess in advance just how much the money will cost us, where the risk is avoided of making assessment only on the basis of the published creditor's interest rate, which is in itself a significant but not the only element in the price of borrowed money. By using the effective interest rate the relationships prevailing on the crediting market become considerably more transparent. In certain European countries there was a rather early prescription of the use of the EIR as basis for comparison of the competitive crediting offers, especially in case of consumer credits, where otherwise (because of unprofessional buyers) the opportunity of fraud were, objectively speaking, much higher than in case of corporate crediting. Hence, even in the most ordinary application of the principle of equivalence of the principal: on the one side we have all the inflows, and on the other all the outflow where EIR corrects both parts of financial flow so that the present values become equal. Parameter EIR is equal to that annual interest rate which is obtained by solving the following equation:

$\sum_{j=1}^{m} \frac{a_{j}}{(1+i)^{t_{j}}}=\sum_{k=1}^{n} \frac{b_{k}}{(1+i)^{t_{k}}}$

Although every economist can perceive with full clarity this equation, for purpose of offering complete elaboration of our topic we shall present in more detail the above stated elements, whose importance is at times rather erroneously interpreted, and we shall offer advice that some additional caution, even for the high professionals, is never superfluous. The symbols designate the following: $\mathrm{M}$ - total number of received amounts; $a_{j}$ - individually received amounts; $t_{i}$ - duration of the annual or under-annual interval from maturity of the first received amount up to the value date of the jth received amount; $n$ - total number of paid amounts; $b_{k}$ - individually paid amounts; $t_{k}$ - duration of the annual or under-annual interval from the moment of maturity of the first received amount up to the value date of the k-th paid amount. As we can see, what occurs are the financial flows which are taking place completely at random (arbitrarily). Time intervals that appear in the nominator on both sides of the equation may be any ones, but each one of them is measured from the maturity of the first amount that the debtor receives on the basis of the credit granted. The required interest rate i may be calculated in three ways: through the algebra solution of the equation, through consecutive approximation, or by means of a computer. Nevertheless, it is recommended that for the sake of precision and efficiency the third option be used for computation. For purpose of a more detailed presentation of the impact that the administrative fixed costs have on the EIR, let us summarize the two simplified examples.

Example 1- What is the effective interest rate at which the money was borrowed if on 1 January 2010 we have taken a loan in the amount of $1,100.00 \$$ and have repaid $1,350.00$ $\$$ on 30 June 2017?

On the left side of the previous equation is the amount of the loan received (from which the interest was not subtracted) because its value date is the starting date for calculation of the interest period. The length of time interval for loan repayment up to 30 June 2011, according to our calculation of days (we are taking into consideration the first day, but not the last day), amounts to 545 days $(365+31+28+31+30+31+29=545)$.

$$
1.100,00=\frac{1.350,00}{(1+i)^{\frac{545}{365}}} \Rightarrow 1+\mathrm{i}=1,1470069 \text { EKS }=14,70 \%
$$

Example 2 - Let us analyze how much the result from the previous example will change if we take into consideration that the debtor had to pay, under the loan agreement, $56 \$$ for administrative costs.

This change means that the debtor, instead of $1,100 \$$, received only $1,044 \$$ which under the same procedure gives us the following EIR:

$$
\begin{aligned}
& 1.044,00=\frac{1.350,00}{(1+i)^{\frac{545}{365}}} \Rightarrow 1+\mathrm{i}=1,1879 \\
& \Rightarrow \mathrm{EKS}=18,80 \%
\end{aligned}
$$

Comparison of the obtained results shows that the basic effect of administrative fixed costs is clearly visible - the loan now costs as if it was granted at an annual interest rate of $18.80 \%$ and 
znači da mora biti zadovoljena sledeća relacija:

$C\left(1-\frac{p_{A, N} x d}{36500}\right)\left(1+\frac{p_{K}}{100}\right)^{d / 365}=C$

Iz ovog obrazca dobijamo izraz za kamatnu stopu $\mathrm{p}_{\mathrm{K}}$ kao funkciju date anticipativne kamatne stope $\mathrm{p}_{\mathrm{AN}^{\prime}}$ i kamatnog perioda:

$p_{K}=100\left(\left(\frac{36500}{36500-p_{A, N} x d}\right)^{365 / d}-1\right)$

Tabela 2. Anicipatvne kamatne stope i prosti kamatni račun ekvivalentne dekurzivnim konformnim kamatnim stopama

\begin{tabular}{|l|c|c|c|c|c|c|}
\hline \multirow{2}{*}{ Dani } & \multicolumn{5}{|c|}{ Kamatna stopa } \\
\cline { 2 - 7 } & $5 \%$ & $7 \%$ & $9 \%$ & $10 \%$ & $12 \%$ & $15 \%$ \\
\hline 5 & $5,13 \%$ & $7,25 \%$ & $9,42 \%$ & $10,52 \%$ & $12,76 \%$ & $16,20 \%$ \\
\hline 10 & $5,13 \%$ & $7,26 \%$ & $9,43 \%$ & $10,53 \%$ & $12,77 \%$ & $16,22 \%$ \\
\hline 15 & $5,13 \%$ & $7,26 \%$ & $9,44 \%$ & $10,54 \%$ & $12,78 \%$ & $16,24 \%$ \\
\hline 20 & $5,14 \%$ & $7,27 \%$ & $9,44 \%$ & $10,55 \%$ & $12,79 \%$ & $16,26 \%$ \\
\hline 25 & $5,14 \%$ & $7,27 \%$ & $9,45 \%$ & $10,56 \%$ & $12,81 \%$ & $16,27 \%$ \\
\hline 30 & $5,14 \%$ & $7,27 \%$ & $9,45 \%$ & $10,56 \%$ & $12,82 \%$ & $16,29 \%$ \\
\hline 60 & $5,15 \%$ & $7,29 \%$ & $9,49 \%$ & $10,61 \%$ & $12,88 \%$ & $16,40 \%$ \\
\hline 90 & $5,16 \%$ & $7,32 \%$ & $9,53 \%$ & $10,66 \%$ & $12,95 \%$ & $16,51 \%$ \\
\hline 120 & $5,17 \%$ & $7,34 \%$ & $9,57 \%$ & $10,70 \%$ & $13,02 \%$ & $16,63 \%$ \\
\hline 180 & $5,19 \%$ & $7,38 \%$ & $9,64 \%$ & $10,80 \%$ & $13,17 \%$ & $16,86 \%$ \\
\hline
\end{tabular}

Na osnovu tabele možemo da zaključimo da nas jednomesečni kredit (30 dana) po anticipativnoj kamatnoj stopi od $10 \%$ p.a. dekurzivno gledano, i uvažavajući konformni obračun košta 10,56\% na godišnjem nivou. Diskontovani iznos koji korisnik kredita primi na početku kreditnog perioda možemo izračunati i na dekurzivan način. Dat je kao odgovor na pitanje: na koju nepoznatu vrednost početne glavnice $C_{0}$ treba obračunati kamate za $d$ dana po datoj kamatnoj stopi (na prosti ili konformni način) da bi dobili krajnji rezultat ekvivalentan ugovorenom iznosu C? U konformnom obračunu dobijamo početni primljeni iznos jednostavnim delenjem konačne glavnice sa konformnim kamatnim faktorom, što odgovara $d$ dnevnoj kapitalizaciji. Ako koristimo prosti kamatni račun $\mathrm{C}_{0}$ se dobija na osnovu sledeće relacije:

$$
\mathrm{C}_{0}=\frac{\mathrm{C}_{0} \mathrm{p}_{\mathrm{N}} \mathrm{d}}{36500}=\mathrm{C} \Rightarrow \mathrm{C}_{0}=\frac{36500 \mathrm{C}}{36500+\mathrm{p}_{\mathrm{N}} \mathrm{d}}
$$

Na osnovu jednog od oblika lako možemo izračunati vreme $d$, koje je obično poznato. Međutim, interesantnije je izračunavanje kamatne stope $\mathrm{p}_{\mathrm{N}}$; kada su ostale veličine poznate. U stvari, čak i ne moraju da budu eksplicitno poznate $\mathrm{C}_{\text {i }} \mathrm{C}_{0}$, dovoljan je samo njihov odnos, za koji se u nekim slučajevima

koristi termin "kurs" naravno, izražen u procentima, u suprotnom se množi sa 100. Pogledajmo sledeći primer.

Po kursu od 99,17 preduzeće je kupilo dekurzivnu diskontnu hartiju od vrednosti koja dospeva za 29 dana. Koliki je prinos te $\mathrm{HoV}$, meren prostim kamatnim računom? Termin "diskontna hartija od vrednosti" obično znači da nominalna vrednost hartije dospeva nakon određenog vremena, koju na početku perioda kupujemo po njenoj diskontovanoj vrednosti. Često se direktno naziva samo kurs, tako da diskontnu stopu treba na osnovu njega samo izračunati. $\mathrm{Na}$ osnovu matematičke formule $\left(^{*}\right) \mathrm{p}_{\mathrm{N}}$ se iznalazi kao funkcija početne i konačne glavnice i vremena za koje se kamata obračunava:

$$
\mathrm{p}_{\mathrm{N}}=\frac{36500\left(\mathrm{C}-\mathrm{C}_{0}\right)}{\mathrm{dC}_{0}}=\frac{36500}{\mathrm{~d}} \frac{100-\mathrm{k}}{\mathrm{k}}
$$

Ovde smo sa $k$ označili "kurs" vrednosnog papira koji govori koliko novčanih jedinica na početku transakcije treba platiti za isplaćenih 100 jedinica na kraju. U našem primeru, na osnovu konkretnih podataka rezultat je sledeći:

$$
\mathrm{p}_{\mathrm{N}}=\frac{36500}{\mathrm{~d}} \frac{100-\mathrm{k}}{\mathrm{k}}=\frac{36500}{29} \frac{100-99,17}{99,17}=10,53398 \ldots \ldots .
$$

ili u procentualnom formatu 10,53\%.

\section{Dugoročne transakcije}

Ovde ćemo analizirati nekoliko primera iz oblasti rente i kredita kao najatraktivnijih dugoročnih poslova. Obična periodična uplata koja u našim uslovima postaje sve aktuelnija je renta. Pojam "renta" znači pravo na povremeno dospevajuće iznose. Problem možemo postaviti na sledeći način: koliko bismo trebali uložiti 
without additional costs. In this context it is also necessary to point out that EIR can not be used for direct comparison of credit transactions if other crediting terms are different.

\section{Short-term transactions}

In order to illustrate differences in performances we shall now create several simplified examples.

For the starters, let us assume that two investments that provide annual return of $11 \%$ are maturing in 183 days. For the first one, simple and for the other conform interest calculations are used. What is the difference in yields and how high should be the annual return on the second investment in order for it to yield at the given moment the same return as the first one?

Return which the first investment makes in 185 days (not a leap year) is equal to:

$$
\begin{aligned}
& \frac{\mathrm{Cpd}}{36500}=\frac{\mathrm{C} \times 1 \times 185}{36500}=0,055753 \ldots . \mathrm{C} \Rightarrow(5,57 \%) \mathrm{C} \\
& \text { The secona investment: }
\end{aligned}
$$

$$
C\left(\left(1+\frac{p}{100}\right)^{d / 365}-1\right)=C(1,1185 / 365-1)=0,05432 \ldots
$$

$$
\mathrm{C} \Rightarrow(5,43 \%) \mathrm{C} .
$$

The difference between these two results is obvious. Those who are more conversant with the absolute and relative errors will say that the difference is more significant if the principal C is higher. Generally speaking, in order for the second investment to reach the same return its annual yield should be such to be worth the following:

$$
\frac{C p_{N} \mathrm{~d}}{36500}=C\left(\left(1+\frac{p_{K}}{100}\right)^{\mathrm{d} / 365}-1\right)
$$

or

$$
\mathrm{p}_{\mathrm{K}}=100\left(\left(1+\frac{\mathrm{p}_{\mathrm{N}} \mathrm{d}}{36500}\right)^{365 / \mathrm{d}}-1\right)
$$

$$
\mathrm{p}_{\mathrm{K}}=100\left(\left(1+\frac{11 \times 185}{36500}\right)^{365 / 185}-1\right)=11,30 \%
$$

On the basis of the numerical illustration and the well known fact that at the given interest rate simple interests within one year are growing faster than the conform ones, we notice that calculation of interest for 185 days, at a rate of $11 \%$, shows that the return obtained with the use of the simple interest calculation is equivalent to the annual conform growth of principal which yields the annual interest rate of $11.30 \%$. Concurrently, the result is not only dependent on the given interest rate, but also on the duration of the transaction. At the given interest rate, the differences are the highest in case of medium-term securities (for example, sixmonth securities). At the annual level, certainly there are no differences as conform interest rate is determined in such a way that the annual return should be equal to the one that would be obtained by the use of the simple interest account. In view of the fact that the conform interest calculation, over the last several years, has become a predominant method for short-term deposits, especially when we are speaking of the banking sector, application of other methods requires for the results to be converted into the equivalent conform interest rate. This especially applies if the digression from conform calculation is joined by the following accompanying elements:

a. Indirect expression of return with the discounted value of investment at the beginning of the transaction; or market price of security as the percentage of its final value, and

b. different ways of calculating days, for example, the application of 360 days as the standard length of the year. ${ }^{1}$ In the context of the above stated, let us analyze the following example.

Let us assume that the debtor will repay in $d$ days the principal $\mathrm{C}$ and the appurtenant decursive interests calculated in the conform method, with the annual interest rate of $p k(\%)$. What would be the amount of the equivalent

1 In this respect, it should be underlined that Europe has systematically been encouraging the implementation of precise day count - Exact/Exact or Actual/Actual, or the implementation of the Japanese method - Actual/365. 
da bi deset godina dobijali na kraju meseca po 5.000,00 dinara, ako je godišnja kamatna stopa $7 \%$, obračun kamata konformni i mesečna kapitalizacija? To je uobičajena početna vrednost 120 postnumerandnih iznosa po 5.000,00 dinara, mesečni diskontni faktor koji se određuje na sličan način je jednak 12-tom korenu godišnjeg diskontnog faktora 1,07. Odgovarajući koren iznosi 1,00565415 zaokruženo na osam decimalnih mesta. Prema formuli sadašnja vrednost postnumerandnih iznosa je:

$\mathrm{S}_{0}=\frac{\mathrm{a}}{\mathrm{q}^{\mathrm{n}}} \frac{\mathrm{q}^{\mathrm{n}}-1}{\mathrm{q}-1}=\frac{5.000}{\left(\sqrt[12]{1,07)^{120}}\right.} \frac{(\sqrt[12]{1,07})^{120}-1}{\sqrt[12]{1,07}-1}$

$\mathrm{S}_{0}=434.770,05 \mathrm{din}$

Dobijeni rezultat pokazuje da bi za deset godina stalne mesečne rente od 5.000,00 dinara trebalo uz datu kamatnu stopu uložiti gotovo 435.000,00 dinara. To je činjenica koja donekle umanjuje atraktivnost takvih transakcija. Ako ovaj zadatak rešimo pomoću realne kamatne stope, koja se može dobiti za takve transakcije od 4 - 5\% godišnje, videćemo da kratkoročno odricanje od likvidnosti može da osigura takav periodični tok ali mnogo bolnije. $S$ tim u vezi možemo da zaključimo da su atraktivne samo rente sa predthodnom dugoročnom štednjom. Pogledajmo sledeći numerički primer, ili još bolje, njegov rezultat.

Izračunajmo visinu potrebnih mesečnih prenumerandnih uplata, ako želimo da 40-godišnjom štednjom priuštimo rentu od 5.000,00 novčanih jedinica mesečno u trajanju od 20 godina, koja će se po 12-mesečnom moratorijumu isplaćivati postnumerandno $\mathrm{uz}$ godišnju kamatnu stopu od 5\%, konformni obračun i mesečnu kapitalizaciju. Sa ovim podacima, iznos mesečne štednje je jednak:

$$
a=\frac{5.000}{(\sqrt[12]{1,05})^{251}} \frac{(\sqrt[12]{1,05})^{240}-1}{(\sqrt[12]{1,05})^{480}-1}=493,26 \mathrm{din}
$$

Primer pokazuje da je moguće sa dovoljno dugim periodom štednje kontrolisati likvidnosna opterećenja i obezbediti dobru rentu.

Nedovoljna razvijenost i dubina tržišta kapitala utiču da srpska preduzeća kao eksterne izvore finansiranja velikim delom koriste kredite.
Svaki izvor finansiranja ima svoju cenu i zadatak finansijske funkcije je da obezbedi da se obavi ciljni posao sa najnižim ukupnim troškovima kapitala. Kreditna ekspanzija u Srbiji počela je pre desetak godina dolaskom velikog broja stranih banaka i pružanjem raznovrsne ponude koja je bezuslovno prihvatana. Velika potreba za eksternim izvorima finansiranja zamagljuje uslove kredita, tako da se mnogo ne razmišlja o kamatama. Kredite možemo grubo podeliti na kratkoročne i dugoročne. Tipična granica između ove dve vrstejejedna godina kao vreme konačnog vraćanja. Za katkoročne kredite koji finansiraju tekuću aktivnost i likvidnost preduzeća koji su pokriveni kratkoročnim izvorima najčešće se koristi prosti kamatni račun. Za dugoročne kredite koji imaju karakter investicionih ulaganja i otplaćuju se po nekoliko godina, najčešće se koristi složeni kamatni račun. Iako kod kreditnih poslova bar u principu, srećemo kako dekurzivni tako i anticipativni obračun kamate, ovde ćemo se fokusirati na prvu verziju.

Kao što je poznato, banke koriste dva načina - rate $i$ anuitet. Prvi način se zasniva na pretpostavci jednakih otplata a sastoji se od iznosa glavnice koji je jednak u svakoj rati i kamate. Kako se otplatom rata smanjuje glavnica i kamata je svaki mesec sve niža jer se obračunava na sve manju glavnicu. Međutim, rata u prvim godinama je veća nego anuitet. Ovaj način otplate je češći kod kredita pravnim licima, koja u računovodstvu plaćanje kamata različito tretiraju.

Anuitet je iznos kojim se otplaćuje kredit ili zajam u određenom vremenskom periodu, odnosno, utvrđeni iznos koji se otplaćuje postepeno prema amortizacionom planu. $U$ anuitet je uključen deo duga i pripadajuće kamate, a određuje se tako da po dospeću dug bude $\mathrm{u}$ potpunosti isplaćen. $\mathrm{U}$ početnim periodima otplate veće je učešće onog dela koji se odnosi na kamatu, a manje dela koji se odnosi na glavnicu. Sa protokom vremena taj odnos se menja $u$ obrnutom smeru. Zakonodavstvo na neki način daje prednost prvom delu: kada dužnik plaća zajmodavcu fiksni iznos on prvo pokriva kamatu (i sve druge troškove), a ono što je preostalo smanjuje dug. Anuitet sa svojom konstantnom visinom kao što je mesečni, primereniji je za transakcije sa fizičkim licima, gde u njihovo ime ali i za njihov račun na anuitet sugeriše njihov 
annual interest rate $p_{N}$ if we were to apply the simple interest formula?

It is a question here of a reverse function whose solution is especially important for those who have already pegged the funds to the conform interest rate, but have however, become inspired by other options. $p_{N}$ is obtained by solving the following equation and thereupon the table is presented.

$$
\mathrm{p}_{\mathrm{N}}=\frac{36500}{\mathrm{~d}}\left(\left(1+\frac{\mathrm{p}_{\mathrm{K}}}{100}\right)^{\mathrm{d} / 365}-1\right)
$$

Table 1 Preview of decursive simple interest rates recalculated into equivalent decursive conform interest rates

\begin{tabular}{|l|c|c|c|c|c|c|}
\hline \multirow{2}{*}{ Days } & \multicolumn{5}{|c|}{ Interest rate } \\
\cline { 2 - 7 } & $5 \%$ & $7 \%$ & $9 \%$ & $10 \%$ & $12 \%$ & $15 \%$ \\
\hline 5 & $4.88 \%$ & $6.77 \%$ & $8.62 \%$ & $9.54 \%$ & $11.34 \%$ & $13.99 \%$ \\
\hline 10 & $4.88 \%$ & $6.77 \%$ & $8.63 \%$ & $9.54 \%$ & $11.35 \%$ & $14.00 \%$ \\
\hline 15 & $4.88 \%$ & $6.78 \%$ & $8.63 \%$ & $9.55 \%$ & $11.36 \%$ & $14.02 \%$ \\
\hline 20 & $4.89 \%$ & $6.78 \%$ & $8.64 \%$ & $9.56 \%$ & $11.37 \%$ & $14.03 \%$ \\
\hline 25 & $4.89 \%$ & $6.78 \%$ & $8.64 \%$ & $9.56 \%$ & $11.38 \%$ & $14.04 \%$ \\
\hline 30 & $4.89 \%$ & $6.78 \%$ & $8.65 \%$ & $9.57 \%$ & $11.39 \%$ & $14.06 \%$ \\
\hline 60 & $4.90 \%$ & $6.80 \%$ & $8.68 \%$ & $9.61 \%$ & $11.44 \%$ & $14.14 \%$ \\
\hline 90 & $4.91 \%$ & $6.82 \%$ & $8.71 \%$ & $9.64 \%$ & $11.49 \%$ & $14.22 \%$ \\
\hline 120 & $4.92 \%$ & $6.84 \%$ & $8.74 \%$ & $9.68 \%$ & $11.55 \%$ & $14.30 \%$ \\
\hline 180 & $4.94 \%$ & $6.88 \%$ & $8.80 \%$ & $9.76 \%$ & $11.66 \%$ & $14.47 \%$ \\
\hline
\end{tabular}

In many cases, we have the option to execute short-term transactions in the manner that the debtor receives a discounted value of some "rounded up" final contracted amount. The discount may be activated both in the anticipatory and in the decursive manner. The first one is characteristic for the classic draft bills, where the draft discount is subtracted from the nominal value of the principal. Similar approach is encountered in the assessment of different treasury bills, similar securities and in other classic short-term crediting deals. For purpose of explaining the differences in calculation, the following example is offered:

The Company has received from the bank an offer for liquidity credit on $d$ days with anticipative simple interest and an annual interest rate of $\mathrm{p}_{\mathrm{AN}}$. How high should the interest rate $p_{k}$ be of the other bank which is using conform decursive calculation with the daily capitalisation in order for the terms of the credit to be equivalent?

First of all, we must not forget that in case of anticipative calculation the basis for interest calculation is the final value of principal. The debtor actually receives (at the beginning) the decreased principal, which means that we are in search of conform annual interest rate $p_{k}$ which will, in an anticipative way, return the decreased principal $C$ to its initial value. This means that the following relation must be satisfied:

$$
C\left(1-\frac{p_{A, N} \times d}{36500}\right)\left(1+\frac{p_{K}}{100}\right)^{d / 365}=C
$$

From this equation we obtain the expression for the interest rate $p_{k}$ as the function of the given anticipative interest rate $\mathrm{p}_{\mathrm{AN}}$ and the interest period:

$$
\mathrm{p}_{\mathrm{K}}=100\left(\left(\frac{36500}{36500-\mathrm{p}_{\mathrm{A}, \mathrm{N}} \mathrm{x}}\right)^{365 / \mathrm{d}}-1\right)
$$

Table 2 Anticipative interest rates and simple interest calculation equivalent to decursive conform interest rates

\begin{tabular}{|l|c|c|c|c|c|c|}
\hline \multirow{2}{*}{ Days } & \multicolumn{5}{|c|}{ Interest rate } \\
\cline { 2 - 7 } & $5 \%$ & $7 \%$ & $9 \%$ & $10 \%$ & $12 \%$ & $15 \%$ \\
\hline 5 & $5.13 \%$ & $7.25 \%$ & $9.42 \%$ & $10.52 \%$ & $12.76 \%$ & $16.20 \%$ \\
\hline 10 & $5.13 \%$ & $7.26 \%$ & $9.43 \%$ & $10.53 \%$ & $12.77 \%$ & $16.22 \%$ \\
\hline 15 & $5.13 \%$ & $7.26 \%$ & $9.44 \%$ & $10.54 \%$ & $12.78 \%$ & $16.24 \%$ \\
\hline 20 & $5.14 \%$ & $7.27 \%$ & $9.44 \%$ & $10.55 \%$ & $12.79 \%$ & $16.26 \%$ \\
\hline 25 & $5.14 \%$ & $7.27 \%$ & $9.45 \%$ & $10.56 \%$ & $12.81 \%$ & $16.27 \%$ \\
\hline 30 & $5.14 \%$ & $7.27 \%$ & $9.45 \%$ & $10.56 \%$ & $12.82 \%$ & $16.29 \%$ \\
\hline 60 & $5.15 \%$ & $7.29 \%$ & $9.49 \%$ & $10.61 \%$ & $12.88 \%$ & $16.40 \%$ \\
\hline 90 & $5.16 \%$ & $7.32 \%$ & $9.53 \%$ & $10.66 \%$ & $12.95 \%$ & $16.51 \%$ \\
\hline 120 & $5.17 \%$ & $7.34 \%$ & $9.57 \%$ & $10.70 \%$ & $13.02 \%$ & $16.63 \%$ \\
\hline 180 & $5.19 \%$ & $7.38 \%$ & $9.64 \%$ & $10.80 \%$ & $13.17 \%$ & $16.86 \%$ \\
\hline
\end{tabular}

On the basis of this Table we can conclude that our one-month credit (30), according to the anticipative interest rate of $10 \%$ p.a., in the decursive aspect, and respecting conform calculation will cost $10.56 \%$ at an annual level. Discounted amount which the credit beneficiary receives at the beginning of the credit period we can calculate also in the decursive manner. 
poslodavac. Razlike između obračuna su jasno vidljive iz sledeća dva primera.

Primer 1. Uzmimo da je preduzeću odobren investicioni kredit u iznosu od $\$ 500.000,00$ po kamatnoj stopi od 7\%, dekurzivni obračun i višegodišnju kapitalizaciju. Kredit treba vratiti u pet postnumerandnih godišnjih rata. Prvi korak je sačinjavanje rasporeda amortizacije. Svaka rata iznosi petinu kredita, odnosno, \$100.000,00. Ostale podatke dobićemo popunjavanjem sledeće tabele:

Tabela 3. Raspored amortizacije (jednake rate)

\begin{tabular}{|l|r|r|r|r|}
\hline God & Anuitet & Kamata & Otplata & $\begin{array}{c}\text { Ostatak } \\
\text { duga }\end{array}$ \\
\hline 0 & - & - & - & $500.000,00$ \\
\hline 1 & $135.000,00$ & $35.000,00$ & $100.000,00$ & $400.000,00$ \\
\hline 2 & $128.000,00$ & $28.000,00$ & $100.000,00$ & $300.000,00$ \\
\hline 3 & $121.000,00$ & $21.000,00$ & $100.000,00$ & $200.000,00$ \\
\hline 4 & $114.000,00$ & $14.000,00$ & $100.000,00$ & $100.000,00$ \\
\hline 5 & $107.000,00$ & $7.000,00$ & $100.000,00$ & - \\
\hline$\Sigma$ & $605.000,00$ & $105.000,00$ & $500.000,00$ & \\
\hline
\end{tabular}

je 5, diskontni faktor $q$ je 1,07.

$$
\begin{aligned}
& \mathrm{a}=\frac{\mathrm{Dq}^{\mathrm{n}}(\mathrm{q}-1)}{\mathrm{q}^{\mathrm{n}}-1}=\frac{500.000 \times 1,07^{5} \times(1,07-1)}{1,07^{5}-1} \\
& \mathrm{a}=121.945,35 \$
\end{aligned}
$$

Od svakog anuiteta se oduzima kamata iz prethodnog ostatka duga i tako dobija otplata za tekuću godinu. Ova otplata zapravo smanjuje ukupnu obavezu. Kao prvo, izračunajmo podatke u prvom redu plana amortizacije:

$$
\begin{aligned}
& a_{1}=121.945,35 ; k_{1}=500.000,00 * 7 / 100= \\
& 35.000,00 ; \\
& Q_{1}=a_{1}-k_{1}=121.945,35-35.000,00=86.945,35 ; \\
& D_{1}=D-Q_{1}=500.000,00-86.945,35=413.054,65 \$ .
\end{aligned}
$$

Analogno tome nastavljamo postupak da bismo dobili ceo raspored amortizacije:
Kamata; i-tog reda se računa od ostatka duga, koji je dat u poslednjoj koloni prethodnog reda. Iznos otplate (četvrta kolona, poslednji red) mora uvek biti jednak početnom dugu; zbir svih kamata i svih otplata mora biti jednak zbiru svih anuiteta (poslednji red u drugoj koloni).

Primer 2. Preduzeću je odobren investicioni kredit u iznosu od \$500.000,00 po kamatnoj stopi od $7 \%$. Obračun kamata je dekurzivni a kapitalizacija višegodišnja. Kredit treba vratiti u pet jednakih postnumerandnih godišnjih anuiteta. Plan amortizacije možemo sastaviti primenom najčešće korišćenog obrasca za računanje anuiteta

$$
\mathrm{a}=\frac{D q^{\mathrm{n}}(\mathrm{q}-1)}{\mathrm{q}^{\mathrm{n}}-1}
$$

Ovaj obrazac je kao osnovni oblik složenog kamatnog računa univerzalanjer se odnosi na bilo koji broj rata i za bilo koji period kapitalizacije. Neophodno je samo da se pobrinemo za to da se diskontni faktor $q$ i broj rata $n$ prilagode ulaznim podacima. Konkretno, u našem primeru kapitalizacija je višegodišnja, broj rata ili anuiteta
Tabela 4. Raspored amortizacije (jednaki anuiteti)

\begin{tabular}{|l|r|r|r|r|}
\hline God & Anuitet & Kamata & Otplata & $\begin{array}{c}\text { Ostatak } \\
\text { duga }\end{array}$ \\
\hline 0 & & - & - & $500.000,00$ \\
\hline 1 & $121.945,35$ & $35.000,00$ & $86.945,35$ & $413.054,65$ \\
\hline 2 & $121.945,35$ & $28.913,83$ & $93.031,52$ & $320.023,13$ \\
\hline 3 & $121.945,35$ & $22.401,62$ & $99.543,73$ & $220.479,40$ \\
\hline 4 & $121.945,35$ & $15.433,56$ & $106.511,79$ & $113.967,61$ \\
\hline 5 & $121.945,35$ & $7.977,73$ & $113.967,61$ & \\
\hline$\Sigma$ & $609.726,74$ & $109.726,74$ & $500.000,00$ & \\
\hline
\end{tabular}

Zbog nespretnosti sa stotinama novčanih jedinica koje se pojavljuju u amortizacionom planu, banka i klijent često pristaju na neku vrstu "zaokruživanja" fiksnog anuiteta radi lakšeg računanja. Cena toga je računanje tzv. kompenzatornog anuiteta, sa kojim se u poslednjem redu plana amortizacije dobija pravi rezultat i zatvara ceo dug. U cilju detaljinijeg objašnjenja postupka poslužimo se podacima iz prethodna dva primera. Uz definisane uslove plaćamo prve četiri godine anuitet u iznosu od $\$ 122.000,00$. Sa poslednjim (petim) anuitetom 
It is given as an answer to the question: on what unknown value of the initial principal $\mathrm{C}_{0}$ we should calculate interests for $\mathrm{d}$ days at the given interest rate (in the simple or conform manner) in order to obtain the final result equivalent to the contracted amount of $\mathrm{C}$ ? In the conform calculation we obtain the initial received amount by simple division of the final principal with conform interest factor, which corresponds to the $\mathrm{d}$ daily capitalisation. If we are to use the simple interest formula, $\mathrm{C}_{0}$ is obtained on the basis of the following relation:

$$
\mathrm{C}_{0}=\frac{\mathrm{C}_{0} \mathrm{p}_{\mathrm{N}} \mathrm{d}}{36500}=\mathrm{C} \Rightarrow \mathrm{C}_{0}=\frac{36500 \mathrm{C}}{36500+\mathrm{p}_{\mathrm{N}} \mathrm{d}}
$$

On the basis of one of the shapes, we can easily calculate time $d$, which is usually known. However, more interesting is calculation of the interest rate $\mathrm{p}_{\mathrm{N}}$ when the other values are known. In actual fact, even $C$ and $\mathrm{C}_{0}$ do not have to be explicitly known as their ratio is sufficient, for which in some cases the term "price" is used and expressed, of course, in percentages, or in the case of contrary it is multiplied by 100 .

Let us have a look at the following example.

The Company has bought, at the market price of 99.17, decursive discounted security which matures in 29 days. How high is the yield of this security measured by the simple interest account? The term "discounted security" usually means that the nominal value of security matures after a certain period of time, which we are at the beginning of the period buying at its discounted value. It is often directly called the market price so that the discount rate should be only calculated on its basis. On the basis of the mathematical formula $\left(^{*}\right) \mathrm{p}_{\mathrm{N}}$ is derived as the function of the initial and final principal and the time for which interest is calculated:

$$
\mathrm{p}_{\mathrm{N}}=\frac{36500\left(\mathrm{C}-\mathrm{C}_{0}\right)}{\mathrm{dC}_{0}}=\frac{36500}{\mathrm{~d}} \frac{100-\mathrm{k}}{\mathrm{k}}
$$

Here we have designated with $k$ the "market price" of security which speaks of how many monetary units should be paid at the beginning of the transaction for the paid 100 units at the end. In our example, on the basis of concrete data, the result is as follows:

$$
\mathrm{p}_{\mathrm{N}}=\frac{36500}{\mathrm{~d}} \frac{100-\mathrm{k}}{\mathrm{k}}=\frac{36500}{29} \frac{100-99,17}{99,17}=10,53398 \ldots \ldots
$$

or in the percentage format, $10.53 \%$.

\section{Long-term transactions}

We shall analyze here several examples in the field of annuity and credit as the most attractive long-term deals. A simple periodic payment, which in our circumstances is becoming increasingly attractive, is the annuity. The term "annuity" (postnumerando) designates the right to periodic due amounts. We can present the problem in the following manner: how much money should a person invest in order to receive, over a period of ten years, by the end of the month, 5,000.00 dinars, if the annual interest rate is $7 \%$, with conform interest calculation and a monthly capitalisation? This is the usual initial value of 120 postnumerandi amounts of 5,000.00 dinars, monthly discounting factor which is determined in the similar way is equal to the 12th root of the annual discounting factor 1.07. Corresponding root amounts to 1.00565415 rounded up to eight decimal places. According to the formula, the present value of the postnumerandi amounts is the following:

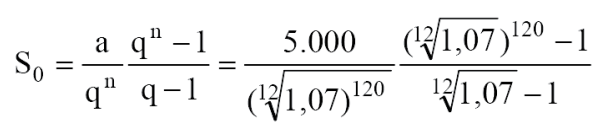

$\mathrm{S}_{0}=434.770,05 \mathrm{din}$

The result obtained shows that for ten years of permanent monthly annuities of 5,000.00 dinars, together with the given interest rate, what should be invested is almost $435,000.00$ dinars. This is the fact that somewhat lowers attraction of such transactions. If we are to solve this exercise by means of the real interest rate, which may be obtained for such transactions of $4-5 \%$ per annum, we will see that shortterm renouncing on liquidity may insure such a periodic flow, but much more painfully. To that end we may conclude that only those annuities are attractive that are linked with previous long-term savings. Let us have a look at the following numerical example, or even better, let us see its result.

Let us calculate the amount of necessary monthly prenumerandi payments if we wish to secure, from 40-year long savings, an annuity of 5,000.00 monetary units per month, in 
konačno amortizujemo dug. Najjednostavnije je izračunati prva četiri reda amortizacionog plana (peti $=0$ ), i na kraju utvrditi iznos poslednjeg anuiteta. Koristeći navedene informacije završimo raspored amortizacije:

Tabela 5. Anuitet izjednačavanja i raspored amortizacije

\begin{tabular}{|l|r|r|r|r|}
\hline God & Anuitet & Kamata & Otplata & \multicolumn{1}{c|}{$\begin{array}{c}\text { Ostatak } \\
\text { duga }\end{array}$} \\
\hline 0 & & - & - & $500.000,00$ \\
\hline 1 & $122.000,00$ & $35.000,00$ & $87.000,00$ & $413.000,00$ \\
\hline 2 & $122.000,00$ & $28.910,00$ & $93.090,00$ & $319.910,00$ \\
\hline 3 & $122.000,00$ & $22.393,70$ & $99.606,30$ & $220.303,70$ \\
\hline 4 & $122.000,00$ & $15.421,26$ & $106.578,74$ & $113.724,96$ \\
\hline 5 & $121.685,71$ & $7.960,75$ & $113.724,96$ & \\
\hline$\Sigma$ & $609.685,71$ & $109.685,71$ & $500.000,00$ & \\
\hline
\end{tabular}

Poslednji (peti) anuitet se obračunava kao iznos ostatka duga do pretposlednje rate i pripadajuće kamate:

$\mathrm{a}_{5}=\mathrm{D}_{4}+\frac{\mathrm{D}_{4} \mathrm{p}}{100}=\mathrm{D}_{4} \mathrm{q}=113.724,6 \times 1,07=121.685,71 \$$

Kamata se dobija kao razlika

$a_{5}-Q_{5}=121.685,71-113.724,96=7.960,75 \$$.

\section{Interna stopa prinosa}

Kada se razmatra opravdanost datog investicionog projekta koristi se kao glavni kriterijum tzv. neto sadašnja vrednost (NSV). Investicija je ulaganje koje se vrši u sadašnjosti, a od koje se prihodi i koristi očekuju u budućnosti. Da bi se budući troškovi i koristi mogli sabrati neophodno ih je svesti na sadašnju vrednost. NSV je zbir neto pozitivnih efekata projekta iz njegovog ekonomskog toka, aktuelizovanih na sadašnju vrednost predviđenom kamatnom stopom. Da bi projekat bio prihvatljiv neto sadašnja vrednost mora biti veća od nule, što znači da pozitivni efekti projekta nadmašuju troškove ulaganja (Schlosser, 2002. str. 29-30). NSV je opadajuća funkcija diskontne stope, a na dovoljno visokom nivou postaje negativna. Opšta formula za računanje NSV je:

$$
\mathrm{NSV}=\sum \frac{\mathrm{C}_{\mathrm{i}}}{(1+\mathrm{k})^{\mathrm{i}}}
$$

gde je: $C_{i}$ - novčani tok (+ ili -) u periodu $i$; $\mathrm{i}$ - broj perioda; $\mathrm{r}$ - diskontna stopa ili trošak kapitala.

Diskontna stopa koja izjednačava sadašnju vrednost troškova sa sadašnjom vrednosti očekivanih novčanih primitaka od investicije naziva se interna stopa prinosa (IRR). Za njeno iznalaženje primenjuje se isti postupak kao kod NSV i upotrebljavaju se iste formule i tablice. Razlika je u tome, što se metodom IRR nastoji iznaći diskontna stopa pri kojoj je NSV jednaka nuli, dok se metodom NSV određuje neto sadašnja vrednost za neku unapred određenu diskontnu stopu. Određivanje sadašnje vrednosti (diskontovanje) jednostavno je obrnuti postupak od složenog kamatnog računa (Van, Horne, 2002. str. 43). Interna stopa prinosa pokazaće maksimalnu kamatnu stopu koju projekat može platiti, a da se ne stvore gubici. Njena prednost je $u$ tome, što ona prikazuje stvarnu profitabilnost projekta i u tom smislu rezultat je razumljiv čak i neupućenima u ovu problematiku. U praksi se problem iznalaženja IRR-a rešava pomoću nekog od softverskih paketa, npr. Excel, koji ga izračunava sa velikom tačnošću ili pomoću tradicionalnih finansijskih tablica. Mi ćemo poći od jednostavnog primera koji možemo rešiti i bez tehničkih pomagala. Znamo da je za IRR karakteristično to da je nepoznata diskontna stopa, a poznate sledeće veličine: (1) neto ukupni primici, (2) broj godina u veku trajanja projekta i (3) sadašnja vrednost projekta, koja je unapred data kao nula.

Sada možemo da izračunamo IRR za projekat koji će na osnovu početnog ulaganja od 100.000,00 \$ u naredne dve godine vratiti po $60.000,00$ \$. Kada znamo da je IRR ona diskontna stopa pri kojoj je NSV projekta jednaka 0 , u zapisu koristimo njen odgovarajući kamatni faktor $r$ koji ja za sada nepoznat. Na taj način se dobije sledeći niz jednačina:

$\frac{\mathrm{a}}{\mathrm{r}}+\frac{\mathrm{a}}{\mathrm{r}^{2}}-\mathrm{I}_{0}=0 \Rightarrow \mathrm{I}_{0} \mathrm{r}^{2}-\mathrm{ar}-\mathrm{a}=0 \Rightarrow 10 \mathrm{r}^{2}-6 \mathrm{r}-6=0$

Zadnji deo jednačine smo dobili tako što smo 
the duration of 20 years, which will be paid, according to the 12-month moratorium, in a postnumerandi manner, with the annual interest rate of $5 \%$, conform calculation and monthly capitalisation. With this data, the amount of monthly savings is equal to the following:

$$
a=\frac{5.000}{(\sqrt[12]{1,05})^{251}} \frac{(\sqrt[12]{1,05})^{240}-1}{(\sqrt[12]{1,05})^{480}-1}=493,26 \mathrm{din}
$$

This example shows that it is possible, with sufficiently long period of savings, to control liquidity of financial burden and secure a good annuity.

Insufficient development and depth of the capital market are causing Serbian companies to use, to a great extent, credits as external sources of financing. Every source of financing has its own price and the task of financial function is to secure that the targeted transaction is to be made at the lowest total cost of capital. Credit expansion in Serbia started some ten years ago with the advent of a large number of foreign banks and the availability of diversified offer which was unreservedly accepted. Great need for external sources of financing is rendering opaque crediting conditions, and not much thought is given to the interest rates. We can broadly divide credits into short-term and long-term ones. The typical crossing line between these two types is one year as the time of final repayment. For the short-term credits which are financing current activities and company liquidity which are covered by short-term sources, what is most often used is the simple interest calculation. For long-term credits which are having the character of investment placements and are repaid over a period of several years, most often used method is the compound interest calculation. Although in credit transactions, at least in principle, we encounter both decursive and the anticipatory interest calculation methods, we shall focus here on the former version.

It is well known that banks are using two ways - instalments and annuity. The first way is based on the assumption of equal repayments and consists of the amount of principal which is equal in every instalment, and the interest. As the principal is decreasing with the instalment repayment, the interest is every month increasingly lower as it is calculated on an ever decreasing principal. However, repayment instalment during the first years is higher than the annuity. This manner of repayment is more frequent in credits granted to legal entities, which are treating interest payment differently in the accounting books.

Annuity is the amount which is used for credit or loan repayment over the given period of time, i.e. determined amount which is repaid periodically according to the amortisation plan. Annuity includes one part of debt and the due interest, and is determined so that the debt, upon maturity, would be fully repaid. In the initial periods of repayment, there is a high share of that part which pertains to the interest, and a smaller share of the part which pertains to the principal. With the passage of time, this ratio is changing in a reverse direction. Legislature in a certain way gives advantages to the first part: when the debtor is paying the creditor a fixed amount, he is firstly covering the interest (and all other costs), and what remains is reducing the debt. Annuity, with its constant amount such as the monthly one, is more appropriate for transactions with physical persons where in their name but also for their account annuity is suggested by their employer. Differences between calculations are clearly visible from the following two examples.

Example 1 - Let us assume that the company was granted an investment loan in the amount of $\$ 500,000.00$ at an interest rate of $7 \%$, decursive calculation and several years of capitalisation. Credit is to be repaid in five postnumerandi annual instalments. The first step is to make a schedule of amortisation. Every instalment is equal to one fifth of the credit, i.e. to \$ $100,000.00$. Other data we will obtain by filling in of the following Table: 
sa obe strane jednačinu podelili sa 10.000,00. Prema obrascu za rešavanje kvadratne jednačine imamo dva rezultata. Pozitivno rešenje jednačine je 1,13066238, IRR je oko 13,07\%. Zašto nije poželjan negativan rezultat, sasvim je jasno. Sada nije teško pretpostaviti kakvu bismo odluku doneli da nam neko ponudi da nam za pozajmljenih $100.000,00 \$$ vrati na kraju prve i druge godine po $60.000,00 \$$.

\section{Inflacija}

Iako ima mnogo korenja i mnogo lica opšta karakteristika inflacije je samo jedna - pad kupovne moći domaće valute. U uslovima visoke inflacije merene rastom cena na malo, dolazi do depresijacije valute, odnosno, do pada njene kupovne moći, a time i do znatnog realnog smanjenja obima novčane obaveze. $U$ takvim uslovima je zaista teško napraviti pravi potez kako bi imovina sačuvala svoju vrednost. U odnosu na bivšu državu gde je inflacija znatno prelazila indeks koji se u ekonomskoj teoriji kvalifikovao kao "hiperinflacija", tekuće stope inflacije su relativno niske. Ali nisu bezopasne. Inflacija sa 6\% na godišnjem nivou za 12 godina prepoloviće realnu vrednost imovine ako nije adekvatno zaštićena, sa inflacijom od $10 \%$, isto će se desiti u nešto više od sedam godina. Imajući u vidu inflatorna očekivanja, nominalna kratkoročna kamatna stopa utiče na realnu kratkoročnu kamatnu stopu (Hubaard, Glenn, 2002. p. 198) Stoga, kamata koja se plaća na zajmovni kapital mora biti iznad stope inflacije

Londonska međubankarska kamatna stopa (LIBOR) i kamatna stopa formirana na njujorškom finansijskom trzistu (PRIME RATE).

Radi pojednostavljenja izračunavanja (bez duplih razlomaka) u formule za izračunavanje realne kamatne stope uvrstićemo kao decimalni broj. Neka je $i$ godišnja kamatna stopa po kojoj smo posudili sredstva, onda $\pi$ znači stopu inflacije. Nakon godinu dana stvarna kupovna moć početne glavnice $C_{0}$ zbog obračuna kamate množi se sa kamatnim faktorom $1+i$ $\mathrm{a} u$ isto vreme, zbog inflacije deli sa faktorom inflacije $1+\pi$. Sve ovo se može izraziti pomoću matematičke formule koja će imati sledeće relacije:

$\mathrm{C}_{0} \Rightarrow \mathrm{C}_{0} \frac{1+\mathrm{i}}{1+\pi}$

Razlomak na desnoj strani formule predstavlja faktor realnog rasta a njegova vrednost može biti:

- veća od 1, kada je kamatna stopa $i$ veća od stope inflacije $\pi$;

- jednaka 1, kada se parametri podudaraju (glavnice održavaju svoju kupovnu moć);

- manja od 1 - kada je kamatna stopa $i$ manja od stope inflacije $\pi$; (glavnica se $u$ ovom slučaju nominalno povećala za $i \%$, međutim, uprkos tome njena kupovna moć se smanjuje (pogodan svakodnevni okrutan primer za to su naši tekući računi).

Faktor realnog rasta izražava se na način karakterističan za faktore, dakle u obliku $1+r$, što predstavlja stopu realnog rasta, ali da ne bi iskomplikovali stvari, realnu kamatnu stopu uvrstićemo kao decimalni broj. Tada možemo iz jednačine $\frac{i+1}{i+\pi}=1+r$ dobiti bilo koji od tri parametra (nominalnu kamatnu stopu $i$, realnu kamatnu stopu $r$ i stopu inflacije $\pi$ ) kao funkciju druge dve. Za praktičnu upotrebu najlakši način je da se zapamti oblik jednačine koji je dobro poznat u našoj praksi već više decenija: $1+\mathrm{i}=(1+\pi)(1+\mathrm{r})$, iako ga mnogi ne razumeju sve dok se ne čita srpski: ukupni kamatni faktor je proizvod

da bi se sačuvala realna vrednost kapitala. Najmerodavnije u određivanju kamata su faktora inflacije i faktora realnog rasta. Ako je ovo nedovoljno brzo preimenujmo prvi faktor 
Table 3: Distribution of amortization (equal installments)

\begin{tabular}{|l|r|r|r|r|}
\hline Year & Annuity & \multicolumn{1}{|c|}{$\begin{array}{c}\text { Interest } \\
\text { rate }\end{array}$} & Repayment & $\begin{array}{c}\text { Outstanding } \\
\text { debt }\end{array}$ \\
\hline 0 & - & - & - & $500,000.00$ \\
\hline 1 & $135,000.00$ & $35,000.00$ & $100,000.00$ & $400,000.00$ \\
\hline 2 & $128,000.00$ & $28,000.00$ & $100,000.00$ & $300,000.00$ \\
\hline 3 & $121,000.00$ & $21,000.00$ & $100,000.00$ & $200,000.00$ \\
\hline 4 & $114,000.00$ & $14,000.00$ & $100,000.00$ & $100,000.00$ \\
\hline 5 & $107,000.00$ & $7,000.00$ & $100,000.00$ & - \\
\hline$\Sigma$ & $605,000.00$ & $105,000.00$ & $500,000.00$ & \\
\hline
\end{tabular}

From every annuity, interest from the previous remains of the debt is subtracted and thus the repayment for the current year is obtained. This repayment is actually reducing the total liability. Firstly, we calculate data in the first row of the amortisation plan: $a_{1}=121,945.35 ; k_{1}=500,000.00 * 7 / 100=35,000.00$; $\mathrm{Q}_{1}=\mathrm{a}_{1}-\mathrm{k}_{1}=121,945.35-35,000.00=86,945.35$; $\mathrm{D}_{1}=\mathrm{D}-\mathrm{Q}_{1}=500,000.00-86,945.35=413,054.65 \$$

Analogous to this we continue the procedure in order to obtain the entire amortisation schedule:
Interest of the $\mathrm{i}$-th order is calculated from the rest of the debt, which is given in the last column of the previous row. The amount of repayment (fourth column, the last row) must always be equal to the initial debt; the sum of all interests and all repayments must be equal to the sum of all annuities (last row in the second column).

Example 2 - The Company was granted an investment credit in the amount of $\$$ $500,000.00$ at an interest rate of $7 \%$. Calculation of interest is decursive and capitalisation is over several years. Credit is to be repaid in five equal postnumerandi annual annuities. Amortisation plan can be made by applying the most frequently used format for calculation of annuities

$\mathrm{a}=\frac{\mathrm{Dq}^{\mathrm{n}}(\mathrm{q}-1)}{\mathrm{q}^{\mathrm{1}}-1}$.

This format is universal as the basic format of compound interest account, and it pertains to any given number of instalments and to any period of capitalisation. It is necessary only to pay attention that the discount factor $q$ and the number of instalments $\mathrm{n}$ are adjusted to the input data. In concrete terms, in our example, capitalisation is several years long, number of instalments or annuities is 5, and discounting factor $q$ is 1.07 .

$\mathrm{a}=\frac{\mathrm{Dq}^{\mathrm{n}}(\mathrm{q}-1)}{\mathrm{q}^{\mathrm{n}}-1}=\frac{500.000 \times 1,07^{5} \times(1,07-1)}{1,07^{5}-1}$

$\mathrm{a}=121.945,35 \$$
Table 4. Distribution of amortization (equal annuities)

\begin{tabular}{|l|r|r|r|r|}
\hline Year & \multicolumn{1}{|c|}{ Annuity } & \multicolumn{1}{c|}{$\begin{array}{c}\text { Interest } \\
\text { rate }\end{array}$} & Repayment & $\begin{array}{c}\text { Outstanding } \\
\text { debt }\end{array}$ \\
\hline 0 & & - & - & $500,000.00$ \\
\hline 1 & $121,945.35$ & $35,000.00$ & $86,945.35$ & $413,054.65$ \\
\hline 2 & $121,945.35$ & $28,913.83$ & $93,031.52$ & $320,023.13$ \\
\hline 3 & $121,945.35$ & $22,401.62$ & $99,543.73$ & $220,479.40$ \\
\hline 4 & $121,945.35$ & $15,433.56$ & $106,511.79$ & $113,967.61$ \\
\hline 5 & $121,945.35$ & $7,977.73$ & $113,967.61$ & \\
\hline$\Sigma$ & $609,726.74$ & $109,726.74$ & $500,000.00$ & \\
\hline
\end{tabular}

Because of inconvenience with hundreds of monetary units which appear in the amortisation plan, the bank and its client often accede to some kind of "rounding up" of the fixed annuity for purpose of easier calculation. The price of this is calculation of the so-called compensation annuity with which, in the last row of the amortisation schedule, the real result is obtained and the entire debt is closed. For purpose of more detailed explanation of the procedure we shall use data from the previous two examples. With defined conditions, we are paying annuity for the first four years in the amount of $\$ 122.000 .00$. With the last (fifth) annuity we are finally amortising the debt. The simplest procedure is to calculate the first four rows of the amortisation schedule (fifth $=0$ ), and finally to determine the amount of the last annuity. Using the above said information, we will complete the amortisation schedule (Table 5). 
na desnoj strani u revalorizacioni faktor. To je njegova uloga, množenje s njim retroaktivno koriguje smanjenu kupovnu moć glavnice usled inflacije. Drugim rečim, početni iznos glavnice množenjem tako ponovo procenjujemo pa važećim cenama u vreme dospeća. Ako se glavnica realno poveća za $r \%$, ukupni kamatni faktor mora biti proizvod revalorizacionog fktora i kamatnog faktora koji odgovara datoj realnoj kamatnoj stopi. U matematičkom izrazu ovim pravilom možemo eliminasati zagrade na desnoj strani jednačine i oduzimanjem 1 na obe strane dobiti čuvenu Fišerovu jednačinu: $\mathrm{i}=\pi+\mathrm{r}+\pi \mathrm{r}$. Ekonomista Irving Fišer (Irving Fisher) je realnu kamatnu stopu definisao kao nominalnu kamatnu stopu umanjenu za stopu očekivane inflacije u vreme dospeća, (Brealey, Myers, 2002. p. 792).

Zadatak: Pretpostavimo da je u zemlji stopa inflacije 7,00 \% i da se za kašnjenje u plaćanju primenjuje realna kamatna stopa $14,10 \%$. Kolika je nominalna kamatna stopa u skladu sa ovim pretpostavkama ako se koristi a) obrazac bez drugog člana ili b) upravo Fišerova jednačina.?

$\mathrm{U}$ prvom primeru sabiranjem obe stope dobijemo da je $\mathrm{i}=\pi+\mathrm{r}=0,070+0,141=0,211$, odnosno, $i=21,10 \%$.

Prema Fišeru imamo: $\mathrm{i}=\pi+\mathrm{r}+\pi \mathrm{r}=0,070+0,141+0,070 \times 0,141=0,22087$.

Drugim rečima, pravilno izračunata nominalna kamatna stopa iznosi 22,09\%. Razlika između ove dve vrednosti je za većinu ekonomista ogromna, međutim, neki ipak smatraju da se može zanemariti. Obrnimo zadatak i postavimo pitanje na sledeći način: kolika je realna kamatna stopa koju smo primenili kada smo pri godišnjoj inflaciji od $7 \%$ poslovnom partneru naplatili kamate po nominalnoj kamatnoj stopi od 21,10\%? Zadatak je najlakše rešiti pomoću "faktora": nominalni faktor"je 1,2110, a inflacioni 1,070. Imajući u vidu činjenicu da je nominalni faktor proizvod inflacionog i nepoznatog realnog faktora, dobijamo sledeće rešenje:

$1,070 \times(1+r)=1,211$

$\Rightarrow(1+r)=\frac{1,211}{1,070}=1,1317765 \ldots . . \Rightarrow r \approx 0,1317$

$\mathrm{Na}$ ovaj način dobijena realna kamatna stopa iznosi svega 13,18\% umesto "načelnih" $14,10 \%$. Šta to znači za entuzijazam kreditora za pozajmljivanje novca sasvim je jasno.

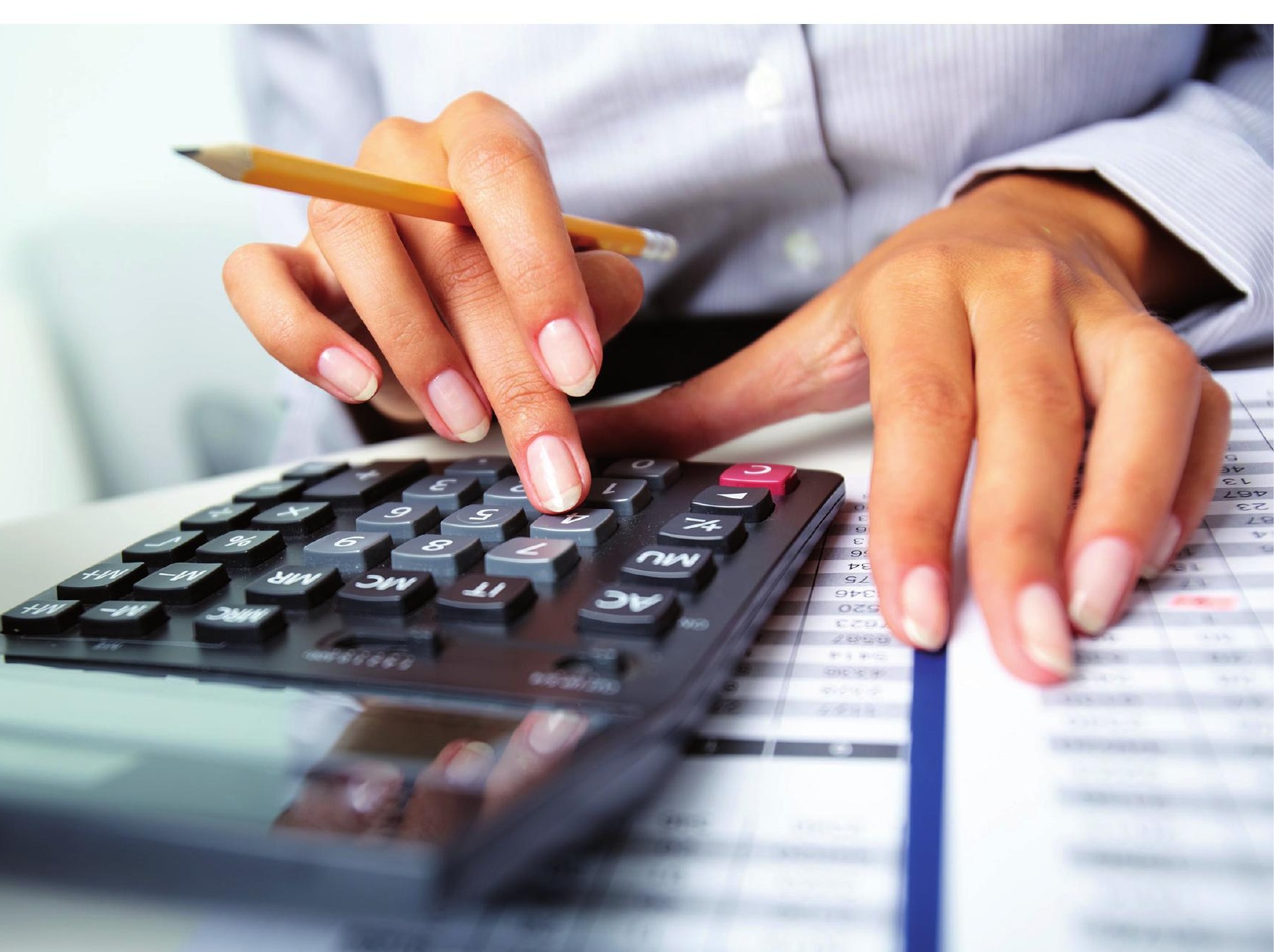


Table 5 Equalization annuity and amortization schedule

\begin{tabular}{|l|r|r|r|r|}
\hline Year & \multicolumn{1}{|c|}{ Annuity } & Interest rate & Repayment & $\begin{array}{c}\text { Outstanding } \\
\text { debt }\end{array}$ \\
\hline 0 & & - & - & $500.000,00$ \\
\hline 1 & $122.000,00$ & $35.000,00$ & $87.000,00$ & $413.000,00$ \\
\hline 2 & $122.000,00$ & $28.910,00$ & $93.090,00$ & $319.910,00$ \\
\hline 3 & $122.000,00$ & $22.393,70$ & $99.606,30$ & $220.303,70$ \\
\hline 4 & $122.000,00$ & $15.421,26$ & $106.578,74$ & $113.724,96$ \\
\hline 5 & $121.685,71$ & $7.960,75$ & $113.724,96$ & \\
\hline$\Sigma$ & $609.685,71$ & $109.685,71$ & $500.000,00$ & \\
\hline
\end{tabular}

The last (fifth) annuity is calculated as the amount of the rest of the debt up to the one before last instalment and the appurtenant interest:

$\mathrm{a}_{5}=\mathrm{D}_{4}+\frac{\mathrm{D}_{4} \mathrm{p}}{100}=\mathrm{D}_{4} \mathrm{q}=113.724,6 \times 1,07=121.685,71 \$$

Interest is obtained as the difference between:

$a_{5}-Q_{5}=121,685.71-113,724.96=7,960.75 \$$

\section{Internal Rate of Return (IRR)}

When there is deliberation on how justified an investment project is, what is used as the main criterion is the so-called net present value (NPV). Investment is placement of money which is being made in the present time, and where return and benefits are expected in the future. In order to be able to calculate future costs and benefits it is necessary to bring them down to their present value. NPV is the sum of net positive effects of the project from its economic flow, updated to the present value through the foreseen interest rate. In order for a project to be acceptable, net present value must be higher than zero, which means that the positive project effects should exceed investment costs (Schlosser, 2002, p. 29-30). NPV is a declining function of the discount rate, and at a sufficiently high level it becomes negative. General formula for calculating NPV is the following:

$$
\mathrm{NSV}=\sum \frac{\mathrm{C}_{\mathrm{i}}}{(1+\mathrm{k})^{\mathrm{i}}}
$$

Where $\mathrm{C}_{\mathrm{i}}$ is cash flow (+ or -) in the period $i$; $\mathrm{i}$ - the number of periods; $\mathrm{r}$ - discount rate or cost of capital.

The discount rate which equalizes present value of costs with the present value of expected cash receipts from investment is called internal rate of return (IRR). In order to find the IRR the same procedure is applied as that for the NPV and the same formulas and tables are used. The difference is that the IRR method is trying to find the discount rate at which the NPV is equal to zero, while the NPV method is determining net present value for some in advance determined discount rate. Determination of the present value (discounting) is simply the reverse procedure of the compound interest calculation (Van, Horne, 2002 , p. 43). Internal rate of return will show the maximum interest rate which the project can afford to pay, without making losses. Its advantage is that it shows the real profitability of the project and in that sense the result is comprehensible even for those least versed in this field of work. In practice, problem in finding the IRR is resolved by means of some software packages, for example Excel, which is calculating it with great precision or by means of traditional financial tables. We shall start from the simple example which we can solve even without technical assistance. We know that it is characteristic for the IRR that the discount rate is not known, while the known values are the following: (1) net total receipts, (2) number of years in the project life cycle, and (3) present value of the project, which is in advance given as zero.

Now we can calculate the IRR for the project which will on the basis of initial investment of $100,000.00$ \$ over the next two years, return $60,000.00 \$$ for each. When we know that the IRR is that discount rate at which the NPV of the project is equal to zero, in the writ we are using its corresponding interest factor $r$ which is at present unknown. In this way we can obtain the following equation series:

$\frac{\mathrm{a}}{\mathrm{r}}+\frac{\mathrm{a}}{\mathrm{r}^{2}}-\mathrm{I}_{0}=0 \Rightarrow \mathrm{I}_{0} \mathrm{r}^{2}-\mathrm{ar}-\mathrm{a}=0 \Rightarrow 10 \mathrm{r}^{2}-6 \mathrm{r}-6=0$

The last part of the equation we have obtained by dividing both sides of the equation with 10,000.00. According to the format for solution of the square equation we have two results. Positive solution of the equation is 1.13066238 , IRR is around $13.7 \%$. That is why 


\section{Zaključak}

Kamate kao sastavni deo finansijskih rashoda i prihoda za većinu preduzeća su jedna od ključnih komponenti dobitka ili gubitka. Stoga, gotovo da nema računovođa koji se barem posredno nisu bavili kamatama. Uprkos tome, stiče se utisak da se u praksi ovoj problematici mnogo manje pažnje posvećuje nego što je potrebno. Odgovarajući iznosi se suviše često uzimaju kao dati, neproblematični ili pak "nedodirljivi". Ovakva situacija se može barem delimično objasniti činjenicom da je pouzdanost znanja u oblasti obračuna kamata u proseku skromna. Isto se odnosi i na ostale veštine, posebno u situacijama aktivnog suočavanja sa poslovnim partnerima koji se uglavnom plaše zamki koje u sebi skrivaju pojedini metodi obračuna kamata jer ne žele da rizikuju. Da bismo prevazišli ovakvo stanje neophodna su znanja koja se grubo mogu razdvojiti na ona koja su potpuno univerzalna, koja se mogu gotovo $\mathrm{u}$ neizmenjenom obliku primeniti na način prikazan u stranim udžbenicima iz finansijske matematike i ona koja su naročito srpski obojena i zahtevaju specifičan tretman. Poslednjih je mnogo manje, skoro pa nedovoljno. Primeri dati u ovom radu upućuju na zaključak da je neophodno obratiti pažnju na razlike u obračunima prilikom procene prikladnosti i korektnosti primene određenog metoda obračuna kamata. Suočavanje sa stvarnim dugom je nešto što se ne može izbeći ako je dug već nastao. O zaduživanju se moralo voditi računa kod donošenja poslovnih odluka. $\mathrm{Uz}$ sve to, da bismo bili sigurni da naše preduzeće uredno može servisirati dug po kreditu i tekuće obaveze koje nastaju po tom osnovu, neophodno je uraditi poslovni plan koji će pomoći u donošenju ispravne odluke kada je u pitanju kreditno zaduženje, a potom i da uverimo kreditora da se radi o isplativom poslovnom poduhvatu. Drugim rečima, neophodno je razmotriti opravdanost investicije koja će se finansirati na ovaj način jer nepromišljena odluka može dugoročno opteretiti preduzeće. 
negative result is not desirable, that is quite clear. It is not difficult now to assume what is the decision that we would make if someone offered us that for our borrowed 100,000.00 \$ we would repay at the end of the first and the second year 60,000.00 \$ for each year.

\section{Inflation}

Although it has many roots and many faces, general characteristic of inflation is only one the fall in the purchase power of the domestic currency. In the climate of high inflation measured by the growth of retail prices, what occurs is the currency depreciation, i.e. fall of its purchase power, thus a significant real reduction in the volume of monetary liability. In such conditions, it is really very difficult to make the right move in order to preserve value of the property. In respect to the conditions that prevailed in the former state, where inflation considerably exceeded the index which is qualified in economic theory as "hyperinflation", current inflation rates are relatively low. But they are not harmless. Inflation of $6 \%$ on the annual level, in 12 years will cut in half the real value of property if it is not adequately protected, with inflation of $10 \%$ the same will happen in slightly over seven years. Bearing in mind inflationary expectations, nominal short-term interest rate is impacting the real short-term interest rate (Hubaard, Glenn, 2002, p. 198). Hence, interest which is paid on lending capital must be above the inflation rate in order to preserve real value of capital. The most meritorious in determining interest rates are the London Interbank Offered Rate (LIBOR) and the interest rate formed at the New York financial market (PRIME RATE).

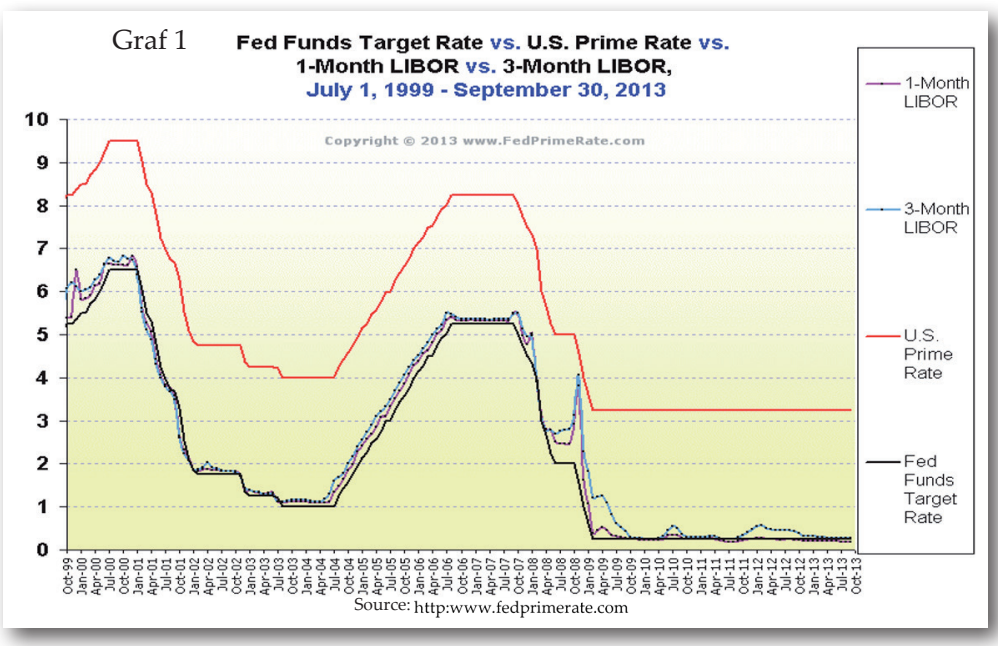

For purpose of simplification of the calculation (without double fractions) in the formula for calculation of the real interest rate we shall insert them as the decimal number. Let us assume that $i$ is the annual interest rate at which we have borrowed money, then $\pi$ designates inflation rate. After one year, the real purchase power of the initial principal $\mathrm{C}_{0}$, because of interest calculation, is multiplied by the interest factor $1+i$ and at the same time, because of inflation it is divided by the inflation factor $1+\pi$. All this can be expressed by means of a mathematical formula which will have the following relations:

$\mathrm{C}_{0} \Rightarrow \mathrm{C}_{0} \frac{1+\mathrm{i}}{1+\pi}$

Fraction on the right side of the formula is the factor of real growth and its value may be the following:

- Higher than 1, when the interest rate $i$ is higher than the inflation rate $\pi$;

- Equal to 1, when parameters are coinciding (principals are reflecting their purchase power);

- Lower than 1 , when the interest rate $i$ is lower than the inflation rate $\pi$; (principal in this case has nominally grown for $i \%$, however, in spite of this its purchase power is falling (an appropriate, yet on daily basis cruel example of this are our own current accounts).

The factor of real growth is expressed in the manner characteristic for factors, therefore in the form of $1+r$, which is the real growth rate, but not to complicate things, we shall classify real interest rate as a decimal number. Then we can from the equation $\frac{i+1}{i+\pi}=1+r$ obtain any of the three parameters (nominal interest rate $i$, real interest rate $r$, and the inflation rate $\pi$ ) as the function of the other two. For practical purposes, the easiest way is to memorize the form of the equation, which is well known in our practice for several decades now: $1+\mathrm{i}=(1+\pi)(1+\mathrm{r})$, although many fail to understand it until it is read in the Serbian language: total interest factor is the product of the inflation factor and the real growth factor. If this is not sufficient, let us quickly rename the first factor on the right-hand side into revaluation factor. This is its role - multiplication with it retroactively corrects the reduced purchase power of the principal because of inflation. In other words, the initial amount of principal, through 


\section{Literatura / References}

1. Brealey, Myers. Principles of corporate finance, Boston, McGraw - Hill Irwin, (2002)

2. Brigham, Eugene \& Houston, Joel. Fundamentals of financial management, Ohio, Thomson South Western, Mason (2004)

3. Chiang, Alpha. Osnovne metode matematičke ekonomije, Zagreb, Marketingtehnologija, 3. izd. (1994)

4. Christian De Lisle. Financial calculations for Business, London, Kogan Page, Ltzd. (1990)

5. Hubaard, Glenn. Money, the Financial Sistem, and the Economy, Boston, $4^{\text {th }}$ ed. Columbia University, [etc.]:Pearson Addison-Wesley, cop. (2002). p.198

6. Ivović Miodrag. Procenat, kamata i kredit u neinflacionim i inflacionim uslovima, Beograd, Savremena administracija, (1988)

7. Madura, Jeff. Financial Markets and Institutions, Thomson, South-Western, Mason, $6^{\text {th }}$ ed. (2003)

8. Marinković, dr Srđan. "Islamsko nasuprot konvencionalnom bankarstvu: uporedna analiza aranžmana finansiranja" Bankarstvo br. 3, (2013). str. 108

9. Mishkin, Frederic. Monetarna ekonomija, bankarstvo i finansijska tržišta, Beograd, Data Status, (2006)
10. Pojatina, dr Davor. "Kamata kao faktor novčane štednje" Bankarstvo br. 7/8, (2010)

11. Rose Peter \& Hudgins Sylvia. Bankarski menadžment i finansijske usluge, Beograd, Data Status, (2005)

12. Schlosser, Michel. Business Finance: applications, models and cases, Harlow [etc.]: Prentice Hall - Financial Times, (2002)

13. Shao Stephen \& Shao Lawrence. Mathematcs for management and Finance, Cincinnati, 5th ed. South-Western Publishing Co. (1986)

14. Van, Horne \& John, Wachowicz. Osnove financijskog menedžmenta, Zagreb, Mate, (2002)

15. Zakon o bankama, "Sl. Glasnik RS", br. 107/2005 i 91/2010

16. Zakon o obligacionim odnosima, "Sl. list SRJ", br. 31/93 i "Sl. list SCG", br. 1/2003 Ustavna povelja

17. Zakon o zaštiti korisnika fnansijskih usluga, "Sl. Glasnik RS", br. 36/2011

18. Zima Petr \& Brown Robert. Mathematcs of Finance, Toronto, $3^{\text {rd }}$ ed. McGraw-Hill, Ryerson Ltd. (1988)

19. Žarkić Joksimović, Nevenka. Upravljanje finansijama, Beograd, Grafoslog, (2001)

20. www.fedprimerate.com (21.10.2013) 
multiplication, is again evaluated according to the prices in force at the time of maturity. If the principal is really increased for $r \%$, the total interest factor must be the product of revaluation factor and the interest factor which corresponds to the given real interest rate. In the mathematical expression, with this rule we can eliminate the brackets on the right-hand side of the equation and by subtraction of 1 on both sides we can obtain the famous Fisher's equation: $i=\pi+r+\pi r$. Economist Irving Fisher defined the real interest rate as the nominal interest rate decreased for the rate of anticipated inflation at the time of maturity (Brealey, Myers, 2002, p. 792).

Exercise: Let us assume that the inflation rate of $7.00 \%$ prevails in the country and that for default payments the real interest rate of $14.10 \%$ is applied. How high is the nominal interest rate in accordance with these assumptions if we are to use a) format without the second member, or b) actually the Fisher's equation?

In the firstcase, if we add both interest rates we obtain the following $\mathrm{i}=\pi+\mathrm{r}+0.070+0.141=0.211$, i.e. $i=21.10 \%$.

According to Fisher, we have the following: $\mathrm{i}=\pi+\mathrm{r}+\pi \mathrm{r}=0.70+0.141+0.070 \times 0.141=0.22087$.

In other words, properly calculated nominal interest rate amounts to $22.09 \%$. The difference between these two values is considered to be an enormous one in the view of most economists, however there are some who are of the mind that it may be disregarded. Let us turn around this exercise and phrase the question in the following way: how high is the real interest rate that we have applied when we have, at an annual inflation of $7 \%$, charged our business partner interests according to the nominal interest rate of $21.10 \%$ ? The exercise is best solved by the "factor": nominal factor is 1.2110, and inflation one is 1.070. Bearing in mind the fact that the nominal factor is the product of inflationary and unknown real factor, we obtain the following solution:

$1,070 x(1+r)=1,211$

$\Rightarrow(1+r)=\frac{1,211}{1,070}=1,1317765 \ldots . \Rightarrow r \approx 0,1317$

In this way the obtained real interest rate amounts to only $13.18 \%$ instead of the "in principle" $14.10 \%$. What this means for the enthusiasm of creditors to be boosted in the director of lending money is crystal clear in this case.

\section{Conclusion}

Interest rates, as the component part of the financial expenditures and revenues, for the majority of companies are one of the crucial components in their profit or loss situation. Hence, there is almost no accountant who had not at least indirectly been engaged in the matter of interest rates. In spite of this, there is an impression that in practice this issue is being devoted much less attention than necessary. Corresponding amounts are by far too often taken for granted, unproblematic or even "untouchable". Such a situation may at least in part be explained by the fact that solid reliable knowledge in the field of interest rates calculation is rather modest on an average. Althoughitpertains also to the other skills, especially in the situations of active encounter with business partners who are mostly afraid of booby traps which are hidden in certain interest rate calculation methods, as they do not wish to be exposed to the risks. In order to overcome such a situation, it is necessary to master knowledge that may be broadly divided into that which is fully universal, and which may in an almost identical form be applied in the manner presented in foreign text books from the field of financial mathematics, and those that have a specific Serbian flavour and require specific treatment. Those latter ones are far fewer in number, almost insufficiently so. Examples given in this paper lead to the conclusion that it is necessary to pay attention to the differences in the calculations during the assessment of feasibility and correct application of certain interest calculation method. Facing the real debt is something that can not be avoided if the money was borrowed. Borrowing had to be given proper attention when making business decisions. Concurrently, in order to be sure that our company can properly service its debt for the credit taken and the current liabilities incurred on that basis, it is necessary to make a business plan which will help in making correct decisions regarding credit indebtedness, and then to convince the creditor that yours is a profitable business venture. In other words, it is necessary to examine justifiability of investment which is to be financed in this manner as any ill advised decision may place a heavy and long-term financial burden on the company. 